\title{
Existence of the Audit Expectation Gap and Its Impact on Stakeholders' Confidence: The Moderating Role of the Financial Reporting Council
}

\author{
Taslima Akther ${ }^{1,2, *}$ and Fengju $\mathrm{Xu}^{1}$ \\ 1 School of Management, Wuhan University of Technology, Wuhan 430070, China; xufengju@whut.edu.cn \\ 2 Department of Accounting \& Information Systems, Jagannath University, Dhaka 1100, Bangladesh \\ * Correspondence: taslima@ais.jnu.ac.bd
}

Received: 27 June 2019; Accepted: 30 December 2019; Published: 25 January 2020

\begin{abstract}
This paper empirically emphasizes the existence of the audit expectation gap and its impact on stakeholders' confidence, moderated by the active role of the financial reporting council. As a maiden attempt to portray the relationship, a higher-order model has been constituted and assessed with the pragmatic exploration, smearing the partial least squares structural equation model (PLS-SEM). The data contains 174 respondents as auditors, investors, investment and credit analysts, and regulatory agencies in Bangladesh. The study explores audit expectation gap from diverse aspects, such as auditors responsibility for fraud detection, meaning, and usefulness of the audit report, auditors providing the non-audit services, auditors' responsibility for going concern reporting, and also an unmet expectation for the other assurance services, such as assurance on the other parts of the annual report beyond the financial statements, like management discussion and analysis and corporate social and environmental disclosure. The findings suggest that the audit expectation gap is negatively related to stakeholders' confidence and the greater the audit expectation gap is, the lower stakeholders' confidence is in the audit. Auditors maintaining perceived independence and improving the level of communication with users will diminish the audit expectation gap and induce stakeholders' confidence simultaneously. Moreover, the active role of the financial reporting council acts as a moderator to ensure the auditors' perceived independence. The result of the study motivates the policymakers to concentrate on the users' audit-related expectations and also intends the importance of independent audit oversight.
\end{abstract}

Keywords: audit expectation gap; auditor's perceived independence; stakeholders' confidence; financial reporting council

\section{Introduction}

The audit performs an indispensable economic function in serving the public interest by reinforcing trust and confidence in financial reporting (Monroe and Woodliff 1994a; ICAEW 2008). Consequently, with the collapse of giants like Enron and WorldCom, innumerable changes have commenced in the guiding construction of statutory auditing since the enactment of the Sarbanes-Oxley Act in 2002, with the goal to reinstate confidence in the audit of financial statements (Howieson 2013; Baker et al. 2014). Nevertheless, for decades, the auditing profession has been disquieted with high levels of litigations and accusations due to the failure of auditors to meet society's expectations, affirming an audit expectation gap (AEG), which, in turn, undermines confidence in the audit function (Porter 1993; Porter and Gowthorpe 2004; Porter et al. 2012). Even on the eve of 2018, due to the collapse of the Carillion Construction Company in the U.K., an audit expectation gap has been discerned from an up-to-the-minute angle, and the users of the audit reports are deeply concerned regarding the matter 
(Stephen 2018). The audit expectation gap is a serious concern in the audit profession (Stevenson 2019), and the greater the breach of expectations is, the lower the credibility, netting potency and esteem attendant with the auditors' function (Sikka et al. 1998)

"Clients have clear role expectations of professionals in people-based services such as accountants, lawyers, doctors and they will evaluate service encounters based on the perceived role performance of the service provider and compliance with those expectations is the important base for evaluating the quality and the effectiveness of the service provided" (Broderick 1999). Barker (2002) proclaims that society's resilience driven by proficient personnel is the "heartbeat of that profession"; hence, if such confidence is betrayed, professionalism is damaged and, subsequently, auditors become ineffective (Porter et al. 2008). According to a research report from the Financial Reporting Council (FRC 2016), the stakeholders' confidence in the audit is closely related to the level of the audit expectation gap and confidence exists when auditors are believed to act independently of 'client' companies, have the competence and position to audit at a high level, are motivated by a combination of pertinent principles and rules, and operate in a fair and open market.

Hence, to rejuvenate society's confidence in the audit functions and to extenuate the litigation and accusation against the auditors, the audit expectation gap should be eliminated, if not significantly reduced (Md Ali et al. 2009). Auditors' independence is the center of the audit expectation gap debate (Humphrey et al. 1992). The greater the auditor independence is, the smaller the audit expectation gap and the higher the confidence in auditors' work (Salehi and Azary 2009; Sikka et al. 1998). The expectation gap is often referred to as the communication gap between the auditors and the clients and users face difficulties in understanding the intended meaning of the audit report (Mock et al. 2012). Standard setters and the auditing profession have evident attention in reducing any communication gap with clients since such a gap can erode confidence in an audit report and trigger unnecessary litigation (AICPA 1978; Gray et al. 2011; Gold et al. 2012; Porter et al. 2012). Although agency theory references the identified statutory persistence of audits as necessary to protect stockholders, the purpose of audits in light of stakeholder theory needs to be aligned with the reality in a multifaceted world, meaning that organizations have other stakeholders (ICAEW 2008). There exists a significant research gap concerning whether the audit expectation gap exists and what are the consequences of such a gap in the contemporary business environment taking the stakeholders' views. However, considering manifold issues, this study introduces three important research questions, such as which factors contribute to form the audit expectation gap, whether the audit expectation gap has any impact on the stakeholders' confidence, and how to mitigate the audit expectation gap to uphold the stakeholder's confidence in audits.

To address our research question, a questionnaire survey was sent to auditors and other stakeholder groups, such as investors, credit and investment analysts, and regulatory agencies in Dhaka City Bangladesh. There exists a crucial position in Bangladesh to explore the stakeholders' perception towards the audit as the country has started its journey towards the independent control of the audit profession for the first time by ordaining the Financial Reporting Act of 2015. As a consequence of this Act, accounting practitioners and professionals flourished beneath the first-hand guiding requisite with the formation of the financial reporting council (FRC), which essentially caused the termination of an era of self-regulation (Shil 2015). As a maiden attempt to portray the relationship, a higher-order model has been constituted and assessed with pragmatic exploration, using the partial least squares structural equation model (PLS-SEM).

This research has made a noteworthy contribution to the audit literature from several perspectives. First, this is the maiden study empirically explaining the relationship of the audit expectation gap with the stakeholders' confidence. Second, this research guides the regulators as each dimension of the audit expectation gap may inform the regulators of which gap exists and how to mitigate this gap to retain greater confidence in the audit. Third, the model depicts that the financial reporting council acts as a moderator to maintain the auditors' perceived independence; this empirical finding institutes the prominence of independent audit oversight worldwide. Finally, in the Bangladesh context, this model 
could be used as a role model to be embraced and implemented to ensure greater confidence in the audit service.

The subsequent segment of this paper presents as follows: A review of the related literature and hypothesis development in Section 2, followed by a description of data and methodology in Section 3 . After that, Section 4 includes the results of the study and Section 5 offers a discussion and explores the study limitations. Section 6 offers final conclusions.

\section{Review of Related Literature and Hypothesis Development}

\subsection{Audit Expectation Gap (AEG)}

The audit expectation gap exists when auditors and the public embrace dissimilar beliefs regarding the auditor's obligations and responsibilities and the messages channeled by the audit report (Porter 1991; Monroe and Woodliff 1994b; Frank et al. 2001; Elliott et al. 2007). The definition of the concept of the audit expectation gap (AEG) is described by Porter (1993) as mainly a reasonableness gap of the difference between what the public believes auditors to achieve and what they can practically be likely to achieve; the performance gap is the gap between the expected standard of performance of auditors' existing duties and auditors' perceived performance, as perceived by the public, and also the standard gap is the difference between what can sensibly be expected from auditors and auditors' existing duties as defined by the law and professional standards.

However, in this study, a clearer picture of the term audit expectation gap is presented from two distinct paradigms: an unreasonable gap, and a sensible gap. The sensible gap has been divided into a sensible performance gap and also a sensible standard gap.

a. Unreasonable gap: The gap between what society believes in their mind what auditors can achieve and what practices they can achieve. It can also be referred to as the failure of the public to understand the aim and scope of the audit and develop unreasonable expectations.

b. Sensible gap:

(i) Sensible performance gap: What society can sensibly expect from the auditors about the actual level of performance of auditors and the standard of performance described by the current regulation.

(ii) Sensible standard gap: What society can sensibly expect from the auditors if there is an amendment in the current legislation based on equitable demand from the participants and if it is cost-effectiveness of doing so.

As auditing is a powerful tool to bolster the stakeholders' confidence with the results of business operations, many expectations are influenced by the role played by the external auditors (Akther and $\mathrm{Xu}$ 2018). There has been a noteworthy expectations gap amid what financial statement customers presume an audit is conveying, and what the audit profession considers it is delivering, and this gap becomes awkward for auditors during a corporate catastrophe, and special attention has been focused on the role of the auditor (Mock et al. 2012).

Users have tremendous expectations regarding the auditor's role for fraud detection and countless researchers have revealed AEG in the areas of auditor's responsibility for fraud detection (Humphrey et al. 1993b; Gay et al. 1997; Best et al. 2001; Lin and Chen 2004; Dixon et al. 2006; Salehi and Azary 2009; Siddiqui et al. 2009; Stirbu 2010; Pourheydari and Abousaiedi 2011; Ruhnke and Schmidt 2014). Although according to the International Auditing and Assurance Standard Board (IAASB 2009a), it is clear that the main concern for the deterrence and discovery of fraud rests with both the management and the governing body of the entity, and the auditor is accountable for attaining reasonable assurance that the financial statements, as a whole, are free from substantial misstatement, there still exists significant expectations regarding the matter.

Nevertheless, there is an imprecise and pragmatic substantiation of significant communication gaps in the audit report, and there has been extensive exertion in shortening these gaps (Porter 2009; 
Asare and Wright 2012; Gold et al. 2012; Mock et al. 2012). Moreover, significant AEG was also found in the dependability and usefulness of the audit report (Best et al. 2001; Fadzly and Ahmad 2004). Users have difficulty in understanding the basic notions in the audit report such as reasonable assurance, materiality, and sampling (Gray et al. 2011). Porter (2009) mentioned that, in the U.K and New Zealand, $47 \%$ of the financial statement users never or seldom read an entity's audit opinion.

Though a chain of moral principles has been espoused, there are criticisms that a mixture of both audit and non-audit services are incompatible (Armstrong and Vincent 1988; Kinney et al. 2004; Wallman 1996; Wolf et al. 1999; Zaman et al. 2011). Salehi and Rostami (2009) instituted that the grounds for plummeting independence are the financial dependency of the auditor on the clientele; audit marketplace antagonism; the endowment of providing non-audit services; and the guiding infrastructure. Due to the inheritance of providing mixed services auditors perform a diverse role at the same time, such as a consultant to the management and also as a liberated auditor to the shareholders; therefore, auditors are prospective in an incompatible locus (Mo Koo and Sim 1999).

After the 2007 banking disaster, the question was raised as to why numerous banks were in distress and that the world's financial organization was at risk, though there was barely any warning regarding the matter (Carson et al. 2012). Management reports on their company's ability to continue as a going concern Financial Accounting Standard Board (FASB 2008; 2011), whereas auditors are required to issue a specific statement in the auditor's report on the appropriateness of management's use of the going concern assumption International Auditing and Assurance Standard Board (IAASB 2012). Audit reports need to contain material uncertainties related to the going concern, as well as first-hand requisites, to encounter the sufficiency of confessions for 'close call' insight of the germane financial reporting framework, while the occasions or surroundings are acknowledged that may cause substantial qualms on an entity's capability to endure as a going concern (IAASB 2009d, 2015a).

The management discussion and analysis segment of an annual report are vital in providing increased information to the markets afar earnings, and it is also worthwhile in forecasting inevitable economic consequences (Bryan and Smith 1997). However, current auditing standards do not entail the auditor to audit the information in the other parts of the annual report as a fragment of the financial statement audit (Mock et al. 2012). Many companies are in the underway of divulging information allied to the sustainability of their business (Mock et al. 2007). Companies craving to augment their reliability and status are further likely to have their sustainability reports assured (Simnett et al. 2009) and investors have an inclination to receive environmental and social responsibility information from a third-party source, therefore, exemplifying trepidations around the credibility of this sort of disclosure (Brown-Liburd and Zamora 2014; Cohen et al. 2011).

Therefore, considering the above-mentioned issues, we constitute the following hypothesis:

Hypothesis 1a (H1a). The audit expectation gap (AEG) is linked with the auditor's responsibility for fraud detection (ARF), meaning and usefulness of the auditor's report (MUA), auditors providing the non-audit services, the expectation for going concern reporting assurance (GCR), and also the expectation for other assurance services $(O A)$.

\subsection{The Auditor's Perceived Independence (API)}

Auditor independence is considered a capstone of the audit profession because it has been assumed to be the foundation for public trust (Nelson 2006; European Commission 2010; Bazerman and Moore 2011; Jamal and Sunder 2011). It has two distinct dimensions, such as independence in-fact, which is an unbiased mental attitude of the auditor, and independence in appearance, which is the perception by a reasonable observer that the auditor has no relationship with an audit client that would suggest a conflict of interest; however, independence in-fact, is unobservable (Beattie et al. 1999). Providing non-audit services creates role conflicts and has deleterious repercussions on objectivity and capability to accomplish an unprejudiced audit (DeFond et al. 2002; Ashbaugh et al. 2003; Lim and 
Tan 2008). Due to the worthwhile compensation for the non-audit services, auditors may act in a way uncomplimentary to the stakeholders to shield their self-absorption (Hendrickson 1998; Umar and Anandarajan 2004). The Big Four can be restricted from providing non-audit services, and there is an increased call to establish 'audit only' firms; it is an effort to bolster competition and stamp out conflicts of interest in the sector (Pickard and Marriage 2018). According to Haddrill (2018), 'There is a loss of confidence in audit, and I think that the industry needs to address that urgently'. In Bangladesh, there is also the dominance of the Big Four firms as some of those have an affiliation with the world's Big Four as foreign accounting firms essentially partner with local firms (Belal et al. 2017).

An auditor tenure of five years or more does influence auditor independence (Yip and Pang 2017). A persistent association between auditor and clientele may induce the auditor to unsuspectingly acclimate to minor flaws in the clientele's financial accounting review that may disguise a flagging monetary stance (Bazerman et al. 1997). Regulators and policymakers are reconsidering the issue of compulsory auditor alternation and making vigorous strides concerning the process (Public Company Accounting Oversight Board PCAOB (2011a)). The audit committee displays an arbitrating function serving to resolve the incongruities between the auditor and the client (Salleh and Stewart 2012). The auditor's independence is protected through effective communication with the active audit committee (Krishnamoorthy et al. 2002). The trio audit function, which involves external auditors, internal auditors, and audit committees, is indispensable for conserving corporate accountability, and the participants should have interconnections and work together in a mutually compassionate way. Moreover, the audit committee should have the supremacy and concern to ask about any dearth (Porter 2009). According to the International Auditing and Assurance Standard Board (IAASB 2009b), 'communication with those charged with governance', and International Auditing and Assurance Standard Board (IAASB 2009c) 'communicating deficiencies in internal control to those charged with governance and management' offer counsel on conveying substances of attention to the governing authority of an entity. Thus, we develop the following hypothesis:

Hypothesis $\mathbf{1 b} \mathbf{( H 1 b ) . ~ A u d i t o r ' s ~ p e r c e i v e d ~ i n d e p e n d e n c e ~ ( A P I ) ~ i s ~ l i n k e d ~ w i t h ~ r e s t r i c t i o n s ~ i n ~ p r o v i d i n g ~}$ non-audit services (RNAS), the mandatory auditors' rotation (MAR), and effective communication with the active audit committee (AAC).

As a cornerstone of bridging the audit expectation gap is to maintain the auditor's perceived independence because without the perceived independence, an audit report would be regarded as nothing more than a company's publicity effort (Wolf et al. 1999). Bazerman et al. (1997) concluded that "audit failures are the natural product of the audit-client relationship" and restricting the auditors providing non-audit work and increasing the independent audit oversight are vital to mitigate the audit-related expectation. Hence, we posit the following hypothesis:

Hypothesis 1c (H1c). The auditor's perceived independence (API) has a negative impact on the audit expectation $\operatorname{gap}(A E G)$.

\subsection{The Auditor's Improved Level of Communication (AILC)}

Expectation gaps may arise due to the lack of proper information communication with the client. Standard setters and the auditing profession have an important and obvious interest in reducing the communication gap, since a gap can erode confidence in an audit report, lead to poor decisions, and trigger unnecessary litigation (American Institute of Certified Public Accountants AICPA (1978); Coram et al. 2011; Haddrill 2011; РCAOB (2011b); Gold et al. 2012; Mock et al. 2012; Porter et al. 2012).

The existing audit report is merely a 'boilerplate', and it is not ample enough for the discernment of the stakeholders regarding the company's exact affairs (Mock et al. 2012). The International Auditing and Assurance Standard Board dispensed ISA 700 and the revised version of ISA 700 (International Auditing and Assurance Standard Board IAASB (2015b)) in a mandate to advance 
the users' apprehension of an audit, the steadfastness of audited financial statements, and ISA 701, incorporating the key audit matters in the audit report (International Auditing and Assurance Standard Board IAASB (2015c)). Collaborating on the key audit matters, revealing the title of the engagement partner in the audit report, and requiring the presentation of the opinion section of the audit report, in the beginning, are some of the changes to be taken to expand the audit report (International Auditing and Assurance Standard Board IAASB (2015a)). Education can be an imperative function in reducing audit-related expectations (Siddiqui et al. 2009). Epstein and Geiger (1994) ascertained that more sophisticated stakeholders are less likely to mandate upper auditor assurance and the anticipation gap could be tapered by amplifying civic cognizance regarding the traits and restrictions of an audit. Monroe and Woodliff (1993) recommended that education might be an effective tactic to taper the audit expectation and communication gap. Therefore, we institute the following hypothesis:

Hypothesis 1d (H1d). The auditor's improved level of communication (AILC) is linked with the expansion of the audit report (EAR) and ensuring audit education (EAED).

Some prior studies suggested that the communication gap exists between auditors and users of financial statements (Nair and Rittenberg 1987; McEnroe and Martens 2001; Best et al. 2001). Regulators of the audit profession tried to ensure that there is a slight, or no gap in what the auditor intends to communicate and what is perceived by the users as a communication gap erodes confidence in the audit report and can trigger needless lawsuits against the profession; hence, better communication on the part of auditors will reduce the audit expectation gap (Asare and Wright 2012). Moreover, Schelluch and Green (1996) found that the long-form audit report reduces the expectation gap over time. Therefore, we posit the following hypothesis:

Hypothesis 1e (H1e). The auditor's improved level of communication (AILC) has a negative impact on the audit expectation gap (AEG).

\subsection{Stakeholder Confidence}

Although agency theory states that the identified statutory persistence of an audit is to shield the stockholders, it is required to resolve the purpose of the audit in light of the stakeholders' theory with realism, as in the multifaceted world; organizations have other stakeholders (Institute of Chartered Accountants of England and Wales (ICAEW 2008). Contemporary corporate scandals and allied audit disasters recommend that there is a severe detachment between what the public anticipates of the auditors and what the auditors presume of themselves, and these fiascos are termed as the trust gap between the auditors and the users of the audited financial statements (Hogan et al. 2008). Being a socially challenged metempsychosis, the greater the expectation gap is, the lower the credibility, earning prospects, and the reputation connected with the auditor's work (Sikka et al. 1998). The buyer of the audit service can expect that the audit service will maintain the highest level of quality to retain the public's confidence (Humphrey et al. 1993a). Hence, meeting society's expectations and bridging the audit expectation gap may act as an important tool for upholding the stakeholder's confidence. Hence, we posit the following hypothesis:

Hypothesis 2 (H2). There exists a negative relationship between the audit expectation gap (AEG) and the stakeholder's confidence (SC).

The crisis of confidence in auditor independence has highlighted the worldwide singular dominance of the Big Four accounting firms and many have urged that such reliance on the Big Four needs to be lessened to increase competition in the audit market. According to Haddrill (2018), "There is a loss of confidence in audit, and I think that the industry needs to address that urgently'. Many believe that although the Big Four's supremacy in the audit marketplace is undisputable, halting their ascendancy 
further could create more independence and innovation as well as competition (FRC 2016), and market competition can lead to audit quality and auditors' independence (Xie 2016). According to a research report from the financial reporting council in the U.K., Financial Reporting Council (FRC 2016), confidence exists when auditors operate independently of 'client' companies. For an audit to be credible, and reliable, it must be performed by someone who is independent and cannot be influenced by position and power (Olagunju 2011). The greater the audit independence is, there is an additional perspective of higher credibility of the audited financial statements (Baotham and Ussahawanitchakit 2009).

Hypothesis 3a (H3a). The auditor's perceived independence (API) has a positive impact on the stakeholder's confidence (SC).

The broader stakeholders group, particularly the general public and the media, fail to understand the purpose and remit of the audit and, therefore, advocate for better communication by the profession to improve the public's understanding of audits. There exists a communication gap among the users regarding the nature of the audit function and also the meaning of the audit report and a forum is needed for the interface among auditors, management, and users of financial statements to boost confidence in audit (Okafor and Otalor 2013). There exists a communication gap among the auditors and users of the financial statements in understanding the message conveyed by the standard audit report although it provides users heightened confidence about the usefulness of audit reports, hence, improvements in the audit reporting model are necessary (Asare and Wright 2012).

Therefore, we constitute the following hypothesis:

Hypothesis $\mathbf{3 b} \mathbf{b} \mathbf{H} 3 \mathbf{b})$. The auditor's improved level of communication (AILC) has a positive impact on the stakeholder's confidence (SC).

\subsection{The Role of Financial Reporting Council (FRC)}

The Bangladesh parliament passed the Financial Reporting Act (FRA) of 2015 and the Financial Reporting Council (FRC) is an important apparatus of the FRA (Hossen 2016; Siddiqui 2018). The responsibilities of FRC include: inaugurating financial reporting requisites for all business entities in the country; comprising the obligation to espouse accounting and auditing touchstones; providing a license to the auditors; accrediting the auditors and endorsing the audit firms; observing and appraising the financial reporting of publicly listed companies; and applying any punishment for the rule violation, as well as imposing acquiescence with the accounting and auditing criteria and the relevant ethical requisites (IFAC 2017). FRC can play a significant role as an independent regulator of the audit profession, as the president of the FRC rightly said: "Self-regulation are no longer there, people are getting affected; so, regulation is needed for the sake of people and the society" (Ahmed 2017). Therefore, the FRC can be the guardian of public interest in Bangladesh and play a large role in ensuring a lesser audit expectation gap and enhanced confidence in the audit.

Therefore, we institute the following hypotheses:

Hypothesis 4a (H4a). The active role of the financial reporting council (FRC) moderates the effect of auditors' perceived independence (API) on the audit expectation gap (AEG). (SC).

Hypothesis $\mathbf{4 b}(\mathbf{H} 4 \mathbf{b})$. The active role of the FRC moderates the effect of the auditors' improved level of communication (AILC) on the audit expectation gap (AEG).

Hypothesis 4c (H4c). The active role of the FRC moderates the effect of auditors' perceived independence (API) on stakeholders' confidence (SC). 
Hypothesis $4 \mathbf{d}(\mathbf{H} 4 \mathbf{d})$. The active role of the FRC) moderates the effect of the auditors' improved level of communication (AILC) on the stakeholders' confidence (SC).

The study's conceptual model is depicted in Figure 1. The order of the construct and the direct and indirect effects are illustrated as well.

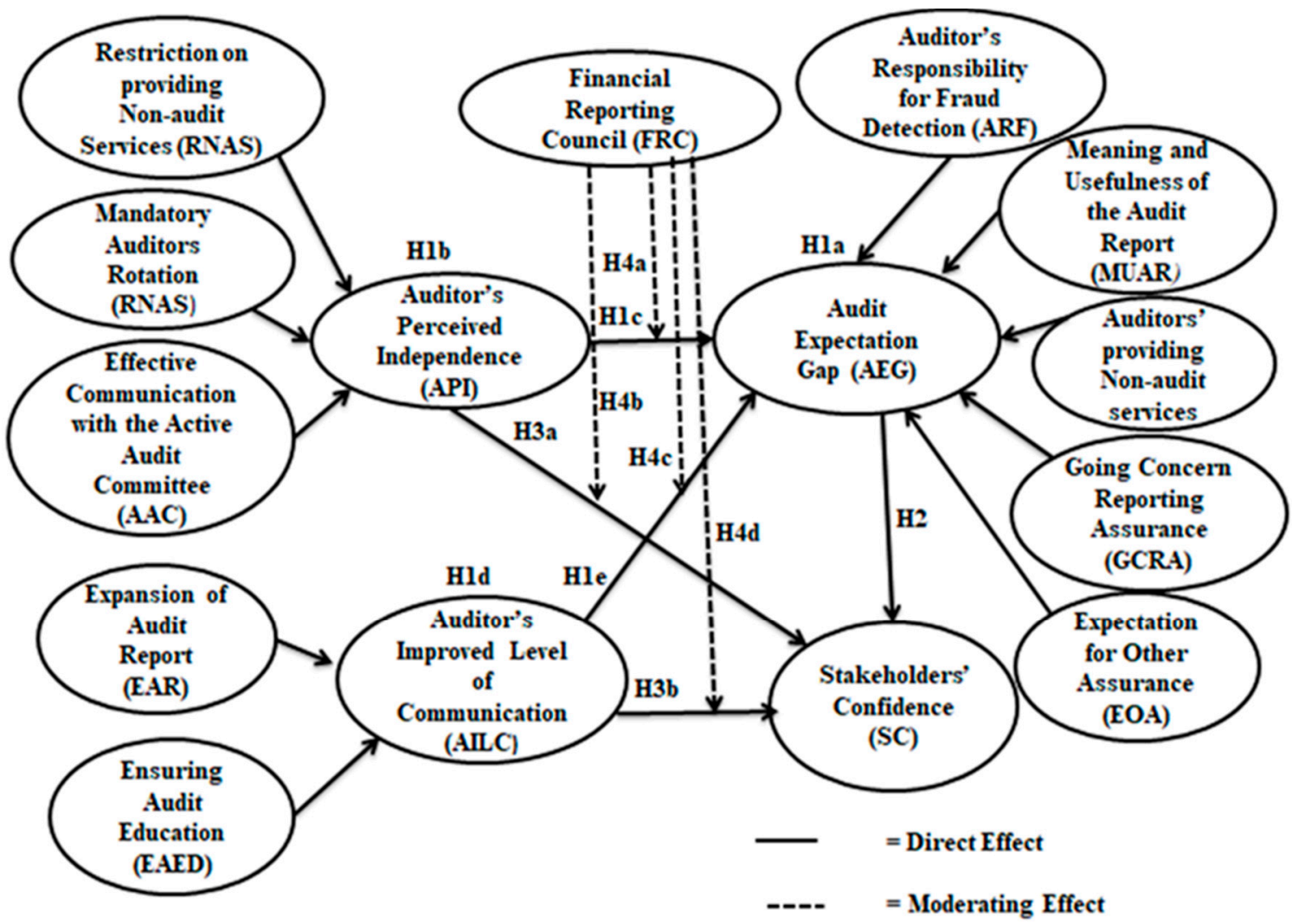

Figure 1. Conceptual model.

\section{Research Method}

\subsection{Data}

A questionnaire has been used as a research instrument as the researchers of the AEG regime mostly used questionnaires (Monroe and Woodliff 1994b; Schelluch and Gay 2006; Ruhnke and Schmidt 2014). In the beginning, the concept of the research and the construct and items development process was discussed with subject experts, university professors, Ph.D. researchers, and chartered accountants. The wide range of academic and professional literature and the contemporary audit standards have been reviewed to develop the research instrument (see Appendix A Table A1). The intended questionnaire was pre-tested by 10 respondents as pre-testing the questionnaire with 5-10 respondents is apposite (Burns and Bush 2003). From the feedback in the pre-testing, some questions were modified, and some were removed considering the importance of each question in our research model. The questionnaire has been designed based on a five-point Likert scale anchored as $5=$ strongly agree; 4 = agree; $3=$ no opinion; $2=$ disagree; 1 = strongly disagree. The questionnaire entailed 42 items and three general questions.

Mainly, auditors and the active players using audit reports, such as investors, credit and investment analysts, and regulatory agencies, have been considered as respondents. A random sampling technique has been used in the study. Auditors include qualified chartered accountants selected randomly from the name list available on the website of the Institute of Chartered Accountants of Bangladesh (ICAB). Investors were selected randomly based on who owns shares in the Dhaka stock exchange (DSE). Credit 
and investor analysts were selected from merchants banks and private commercial banks operated in Dhaka City. Regulatory agencies includes the employees of Bangladesh Securities and Exchange Commission (BSEC), which is the sole regulator of the capital market of the country, Bangladesh bank which is the central bank, and the National Board of Revenues (NBR), which is the authority for tax administration. A face-to-face interview was conducted during the survey and respondents were assured about their anonymity and confidentiality of the information provided. The respondents' groups possess enough accounting and audit qualifications, experience, and most of them are highly educated (see Table 1).

Table 1. Sample characteristics.

\begin{tabular}{|c|c|c|c|c|c|}
\hline \multicolumn{6}{|c|}{ Respondent Group and Basic Question } \\
\hline Variable/Dimension & Frequency & Percentage & Variable/Dimension & Frequency & Percentage \\
\hline $\begin{array}{l}\text { Respondents } \\
\text { Groups }\end{array}$ & & & Read audit report & & \\
\hline Auditors & 33 & 19 & Auditors & 33 & 19 \\
\hline Investors & 42 & 24 & Investors & 6 & 3 \\
\hline Investment Analysts & 36 & 21 & Investment Analysts & 15 & 9 \\
\hline Credit Analysts & 35 & 20 & Credit Analysts & 18 & 10 \\
\hline Regulatory Agencies & 28 & 16 & Regulatory Agencies & 10 & 6 \\
\hline Total & 174 & 100 & Total & 82 & 47 \\
\hline Level of Education & & & $\begin{array}{c}\text { Take Decision } \\
\text { Based on the audit } \\
\text { report }\end{array}$ & & \\
\hline Graduate & 73 & 42 & Auditors & 33 & 19 \\
\hline Post-Graduate & 49 & 28 & Investors & 2 & 1 \\
\hline $\begin{array}{c}\text { Professional Degree, } \\
\text { e.g., } \\
\text { ACA/ACMA/FCA/FCMA }\end{array}$ & 47 & 27 & Investment Analysts & 12 & 7 \\
\hline Ph.D./others & 5 & 3 & Credit Analysts & 15 & 9 \\
\hline Total & 174 & 100 & $\begin{array}{c}\text { Regulatory Agencies } \\
\text { Total }\end{array}$ & $\begin{array}{c}8 \\
70\end{array}$ & $\begin{array}{c}5 \\
40\end{array}$ \\
\hline $\begin{array}{l}\text { Accounting and } \\
\text { Audit related } \\
\text { Experiences }\end{array}$ & & & $\begin{array}{l}\text { Compared with } \\
\text { International } \\
\text { Standards }\end{array}$ & & \\
\hline $1-3$ years & 45 & 26 & Auditors & 24 & 14 \\
\hline $4-6$ years & 72 & 41 & Investors & 4 & 2 \\
\hline $7-9$ years & 36 & 21 & Investment Analysts & 10 & 6 \\
\hline 10 years+ & 21 & 12 & Credit Analysts & 12 & 7 \\
\hline Total & 174 & 100 & $\begin{array}{c}\text { Regulatory Agencies } \\
\text { Total }\end{array}$ & $\begin{array}{l}10 \\
60\end{array}$ & $\begin{array}{c}6 \\
35\end{array}$ \\
\hline
\end{tabular}

Two-hundred fifty respondents were approached and 186 responses were received with a $69.6 \%$ response rate. After removing the incomplete responses, a final sample of 174 usable questionnaires were suitable for analysis. Early respondents (102 cases) and late respondents (72 cases) were divided into two different datasets. A t-test was done to determine the mean differences between these two groups and no significant differences were found; hence, we conclude that the dataset is free from non-response bias. A reliability test of the data has been done in SPSS version 24 software, and the value of Cronbach's alpha was found to be 0.85 , where the acceptable values of alpha ranges from 0.70 to 0.95 (Tavakol and Dennick 2011). The Jarque-Bera test (Jarque and Bera 1980) has been done to assess the normality of the dataset. The result was significant at $p<0.05$, and it shows that the data set is not normal and a nonparametric statistical tool, such as bootstrapping is justified here (Hair et al. 2011). Therefore, using Smart PLS is reasonable with the existing dataset.

\subsection{Methodology}

Data were analyzed in two stages. First, the key constructs Audit Expectation Gap (AEG) was measured using the Mann-Whitney U-test (Nachar 2008) to examine the existence of audit expectation 
gap among the auditors and different stakeholders groups. The Mann-Whitney U-test was only used to measure the key construct of this study, to examine the existence of the audit expectation gap. The result of the Mann-Whitney U-test is included in Table A2. In the second stage, data were analyzed using the structural equation model (SEM) in Smart-PLS version 3.2.7 (Ringle et al. 2015). If the model is complex with many constructs and items, includes a formative construct, does not fulfill the normality assumption of the dataset, deals with a comparatively small sample size, and the predicting key construct is the research goal, using PLS-SEM is more appropriate (Diamantopoulos and Siguaw 2000; Hair et al. 2011). In this study, the focus has been placed on second-order hierarchical latent variable models that include formative relationships. According to Becker et al. (2012) developing a model with a higher-order formative construct is referred to as a type II reflective-formative model. In the case of erecting a type II model, the lower-order constructs are reflectively measured constructs that do not share a common cause but, rather, form a general concept that fully mediates the influence on the following endogenous variables. A PLS-based three-stage approach consistently estimates and tests hierarchical constructs specified as composites of common factors that require three rounds of estimation (Van Riel et al. 2017). The PLS-based three-stage approach has been followed in this study to assess this higher-order model.

Formative indicators are assumed to be error-free (Edwards and Bagozzi 2000). Consequently, the concepts of internal consistency reliability and convergent validity are not meaningful when formative indicators are involved. Instead, theoretical rationale and expert opinion play a more important role in the evaluation of formative indices. Nevertheless, PLS-SEM also offers some statistical criteria for assessing the formative measurement model's quality. According to (Hair et al. 2011), examining each indicator's weight (relative importance) and loading (absolute importance) and applied to bootstrap to assess their significance is important in assessing the formative model. The minimum number of the bootstrap sample is 5000. The examination of measurement properties for a formative construct could be performed by a multicollinearity test, the test of indicator validity (path coefficients significance) and, optionally, if appropriate, a test-retest (Petter et al. 2007).

\section{Results}

The statistics in the sample characteristics display that most of the respondents are highly educated, as $42 \%$ of the respondents are graduates and $41 \%$ of them have $4-6$ years of accounting and audit-related experiences. Despite being knowledgeable in the pertinent field, only $47 \%$ of the total respondents, including the auditors, read an entity's audit report, while investors' groups possess the lowest percentage of reading audit reports, at only $3 \%$. The percentage of making decisions based on audit reports is $40 \%$, including auditors, while only $35 \%$ believe that audit practice in Bangladesh compares well with international standards.

\subsection{Assessing the Measurement Model}

A PLS algorithm was run rather than a consistent PLS algorithm in Smart PLS version 3.2.7. A consistent PLS algorithm assumes the multicollinearity among the constructs and executes an adjustment of the reflective constructs' correlations to sort outcomes consistent with a factor-model (Dijkstra 2010; Dijkstra and Schermelleh-Engel 2014; Dijkstra and Henseler 2015). As it is a formative model, the concept of multicollinearity is absent here, and the PLS algorithm was selected instead of the consistent PLS algorithm. Most of the loadings were significant at $\geq 0.70$ or $\geq 0.50$ (Hair et al. 2011) to form both the first-order construct and the second-order construct. However, any indicator carrying a loading of less than 0.50 has also been retained according to their contribution to forming the construct and assuming there is no impact on the reliability of the constructs.

Theoretically, multicollinearity is desirable for reflective indicators. However, for formative models, multicollinearity is undesirable, due to substantial correlations between formative indicators (Diamantopoulos and Winklhofer 2001; Andreev et al. 2009). To ensure that there is no multicollinearity, each indicator's variance inflation factor (VIF) value should be less than 5 (Hair et al. 2011, 2012); less 
than 3.3 shows an excellent value (Diamantopoulos and Siguaw 2006), and less than 10 shows that no collinearity is commonly accepted (Hair et al. 1995).

The primary statistic for assessing a formative indicator is its weight (Cohen and Cohen 1983). A bootstrapping was done (174 cases, sample 5000). T-statistics of the corresponding weights were found to be significant with a bootstrapping sample at 5000. Weights of the construct were significant and positively contributed to forming the higher-order construct, and all indicators were retained since the rule was supported, although, if an indicator's weight is not significant, the corresponding item loading is relatively high (i.e., $\geq 0.50$ ), or, if it is statistically significant, the indicator should usually be kept. Most of the VIF values were less than 3.3, materializing an excellent measure to form a formative higher-order construct. Table 2 presents the assessment of the measurement model.

Table 2. Assessment of the measurement model.

\begin{tabular}{|c|c|c|c|c|c|c|c|c|c|}
\hline \multicolumn{10}{|c|}{ Formation of First-Order Construct and Items } \\
\hline \multirow{2}{*}{ Path } & \multirow{2}{*}{$\begin{array}{l}\text { Indicator } \\
\text { Loading }\end{array}$} & \multirow{2}{*}{$\begin{array}{l}\text { Indicator } \\
\text { Weight }\end{array}$} & \multirow{2}{*}{ T-stat } & \multirow{2}{*}{ VIF } & \multirow{2}{*}{ Path } & \multirow{2}{*}{$\begin{array}{l}\text { Indicator } \\
\text { Loading }\end{array}$} & \multirow{2}{*}{$\begin{array}{c}\text { Indicator } \\
\text { Weight }\end{array}$} & \multirow{2}{*}{ T-Stat } & \multirow{2}{*}{ VIF } \\
\hline & & & & & & & & & \\
\hline ARF1-ARF & 0.696 & 0.292 & 10.336 & 1.353 & ARF1-AEG & 0.467 & 0.016 & 2.411 & 1.647 \\
\hline ARF2-ARF & 0.914 & 0.312 & 17.922 & 1.537 & ARF2-AEG & 0.470 & 0.006 & 1.988 & 1.575 \\
\hline ARF3-ARF & 0.897 & 0.307 & 17.558 & 4.528 & ARF3-AEG & 0.346 & 0.026 & 2.070 & 4.558 \\
\hline ARF4-ARF & 0.770 & 0.307 & 9.628 & 5.134 & ARF4- AEG & 0.347 & 0.027 & 2.768 & 5.444 \\
\hline MUAR1-MUAR & 0.790 & 0.216 & 16.305 & 2.008 & MUAR1-AEG & 0.556 & 0.004 & 2.081 & 2.271 \\
\hline MUAR2-MUAR & 0.871 & 0.240 & 17.833 & 2.657 & MUAR2-AEG & 0.611 & 0.019 & 2.351 & 2.923 \\
\hline MUAR3-MUAR & 0.794 & 0.237 & 16.795 & 2.024 & MUAR3-AEG & 0.591 & 0.054 & 1.980 & 2.392 \\
\hline MUAR4-MUAR & 0.885 & 0.244 & 20.842 & 2.999 & MUAR4-AEG & 0.623 & 0.114 & 2.068 & 3.325 \\
\hline MUAR5-MUAR & 0.879 & 0.247 & 20.171 & 2.885 & MUAR5-AEG & 0.620 & 0.018 & 2.304 & 3.350 \\
\hline NAS1-NAS & 0.861 & 0.549 & 5.294 & 1.150 & NAS1-AEG & 0.590 & 0.130 & 1.920 & 1.300 \\
\hline NAS2-NAS & 0.893 & 0.590 & 13.797 & 1.391 & NAS2-AEG & 0.662 & 0.119 & 2.866 & 1.637 \\
\hline NAS3-NAS & 0.039 & 0.023 & 13.273 & 1.421 & NAS3-AEG & 0.020 & 0.035 & 1.849 & 1.960 \\
\hline GCRA1-GCR & 0.531 & 0.243 & 5.207 & 1.151 & GCRA1 -AEG & 0.344 & 0.049 & 2.874 & 1.260 \\
\hline GCRA2- GCR & 0.563 & 0.275 & 4.562 & 1.955 & GCRA2 -AEG & 0.420 & 0.120 & 1.924 & 1.206 \\
\hline GCRA3-GCR & 0.808 & 0.440 & 7.735 & 1.419 & GCRA3 -AEG & 0.621 & 0.063 & 1.771 & 1.124 \\
\hline GCRA4-GCR & 0.724 & 0.296 & 7.503 & 1.801 & GCRA4 -AEG & 0.415 & 0.004 & 1.773 & 1.279 \\
\hline OA1-OA & 0.596 & 0.305 & 15.271 & 1.421 & OA1-AEG & 0.409 & 0.127 & 1.845 & 2.053 \\
\hline OA2-OA & 0.833 & 0.485 & 15.295 & 1.426 & OA2-AEG & 0.706 & 0.235 & 1.718 & 2.078 \\
\hline OA3-OA & 0.843 & 0.491 & 2.318 & 1.012 & OA3-AEG & 0.710 & 0.147 & 1.749 & 1.132 \\
\hline RNAS1-RNAS & 0.673 & 0.262 & 8.802 & 1.195 & RNAS1-API & 0.487 & 0.085 & 2.152 & 1.292 \\
\hline RNAS2-RNAS & 0.770 & 0.276 & 13.363 & 1.400 & RNAS2-API & 0.501 & 0.053 & 1.736 & 1.485 \\
\hline RNAS3-RNAS & 0.839 & 0.383 & 18.242 & 1.900 & RNAS3-API & 0.694 & 0.151 & 2.892 & 2.156 \\
\hline MAR 1-MAR & 0.694 & 0.344 & 8.183 & 1.250 & MAR 1-API & 0.442 & 0.042 & 3.938 & 1.333 \\
\hline MAR 2-MAR & 0.839 & 0.411 & 15.504 & 1.565 & MAR 2-API & 0.522 & 0.043 & 3.767 & 2.663 \\
\hline MAR 3- MAR & 0.832 & 0.500 & 14.455 & 1.450 & MAR 3-API & 0.639 & 0.189 & 3.299 & 1.736 \\
\hline CAAC1-AAC & 0.799 & 0.493 & 13.733 & 1.325 & AAC1-API & 0.601 & 0.182 & 3.315 & 1.447 \\
\hline CAAC2-AAC & 0.811 & 0.464 & 13.516 & 1.350 & AAC2-API & 0.564 & 0.083 & 3.456 & 1.510 \\
\hline CAAC $3-A A C$ & 0.633 & 0.363 & 7.551 & 1.114 & AAC3-API & 0.442 & 0.065 & 1.730 & 1.053 \\
\hline EAR1-EAR & 0.725 & 0.214 & 9.301 & 1.961 & EAR1-AILC & 0.488 & 0.062 & 1.772 & 2.041 \\
\hline EAR2-EAR & 0.925 & 0.226 & 10.946 & 2.736 & EAR2-AILC & 0.501 & 0.099 & 1.769 & 2.872 \\
\hline EAR3-EAR & 0.802 & 0.215 & 8.840 & 2.969 & EAR3-AILC & 0.476 & 0.120 & 1.713 & 3.042 \\
\hline EAED1-EAED & 0.843 & 0.510 & 10.410 & 1.306 & EAED1-AILC & 0.587 & 0.230 & 3.450 & 1.495 \\
\hline EAED2-EAED & 0.790 & 0.426 & 12.789 & 1.383 & EAED2-AILC & 0.485 & 0.141 & 2.648 & 1.450 \\
\hline EAED3-EAED & 0.665 & 0.349 & 8.295 & 1.235 & EAED3-AILC & 0.401 & 0.112 & 2.292 & 1.322 \\
\hline SC1-SC & 0.658 & 0.288 & 7.098 & 1.428 & - & - & - & - & - \\
\hline SC2-SC & 0.825 & 0.383 & 10.812 & 1.701 & - & - & - & - & - \\
\hline SC3-SC & 0.823 & 0.344 & 10.833 & 2.733 & - & - & - & - & - \\
\hline SC4-SC & 0.789 & 0.268 & 8.659 & 2.623 & - & - & - & - & - \\
\hline
\end{tabular}

Notes: Bold values are the significant VIF values.

\subsection{Assessing the Structural Model}

A bootstrapping was done with 174 cases, with a sample of 5000, and a good fit found for the structural model (see Figure 2). 


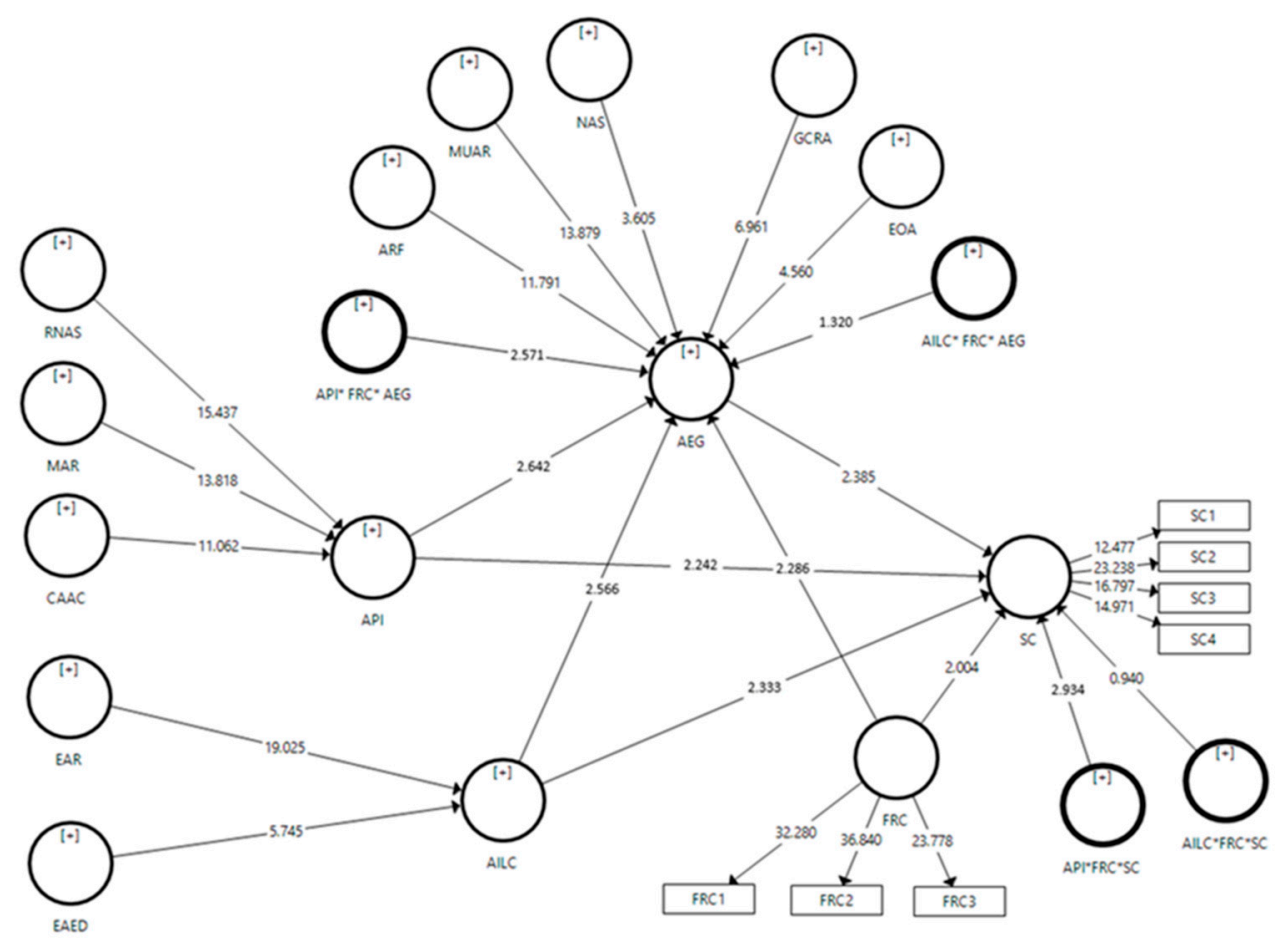

Figure 2. Structural model.

Statistical assessment in Table 3 affirms that AEG is a second-order formative construct designed by five first-order latent constructs, including ARF, MUAR, NAS, GCRA, and EOA, supporting H1a. Statistical assessments in Tables 4 and 5 substantiate that API is a second-order formative construct influenced by three first-order latent constructs, including RNAS, MAR, AAC, supporting $\mathrm{H} 1 \mathrm{~b}$; consequently, AILC is a second-order formative construct deliberated by two first-order latent constructs, including EAR and EAED, respectively, supporting H1C.

Table 3. Formation of second-order constructs AEG, API, and AILC.

\begin{tabular}{|c|c|c|c|c|}
\hline \multicolumn{5}{|c|}{$\begin{array}{c}\text { AEG is Linked with ARF, MUAR, NAS, GCRA and EOA; API is Linked with RNAS, MAR and AAC, } \\
\text { and AILC is Linked with EAR and EAE }\end{array}$} \\
\hline Second-Order Construct & First-Order Construct & Std. Beta & T-Statistic & $p$-Value \\
\hline \multirow[t]{5}{*}{ AEG } & ARF & 0.018 & 11.791 & $0.000^{* * *}$ \\
\hline & MUAR & 0.026 & 13.879 & $0.000 * * *$ \\
\hline & NAS & 0.159 & 3.605 & $0.016^{* *}$ \\
\hline & GCRA & 0.025 & 6.961 & $0.000^{* * *}$ \\
\hline & $\mathrm{EOA}$ & 0.020 & 4.560 & $0.000^{* * *}$ \\
\hline \multirow[t]{3}{*}{ API } & RNAS & 0.031 & 15.437 & $0.000 * * *$ \\
\hline & MAR & 0.029 & 13.818 & $0.000^{* * *}$ \\
\hline & AAC & 0.028 & 11.062 & $0.000^{* * *}$ \\
\hline \multirow[t]{2}{*}{ AILC } & EAR & 0.042 & 19.025 & $0.000^{* * *}$ \\
\hline & EAED & 0.055 & 5.745 & $0.000 * * *$ \\
\hline
\end{tabular}

Notes: $p$ is significant at ${ }^{* * *}(p<0.01),{ }^{* *}(p<0.05)$. 
Table 4. Hypothesis testing of direct relationships.

\begin{tabular}{cccccc}
\multicolumn{7}{c}{ API and AILC Negatively Impact AEG and Positively Impact SC, Whereas a Negative Relation between } \\
AEG and SC \\
Hypothesis & Path & Std. Beta & T-Statistic & $p$-Value & Decision \\
\hline H1c & API -> AEG & -0.013 & 2.642 & $0.000^{* * *}$ & Supported \\
H1e & AILC -> AEG & -0.050 & 2.566 & $0.000^{* * *}$ & Supported \\
H2 & AEG -> SC & -0.123 & 2.385 & $0.035^{* *}$ & Supported \\
H3a & API -> SC & 0.100 & 2.242 & $0.030^{* *}$ & Supported \\
H3b & AILC -> SC & 0.060 & 2.333 & $0.020^{* *}$ & Supported \\
\hline
\end{tabular}

Notes: $p$ is significant at ${ }^{* * *}(p<0.01),{ }^{* *}(p<0.05)$.

Table 5. Hypothesis testing of moderating relationships.

\begin{tabular}{cccccc}
\hline \multicolumn{5}{c}{ FRC Positively Moderates to Ensure Auditors' Perceived Independence (API) } \\
\hline Hypothesis & Path & Std. Beta & T-Statistic & $p$-Value & Decision \\
\hline H4a & FRC $^{*}$ API -> AEG & -0.017 & 2.571 & $0.010^{* *}$ & Supported \\
H4b & FRC $^{*}$ AILC -> AEG & -0.104 & 0.940 & 0.348 & Unsupported \\
H4c & FRC $^{*}$ API -> SC & 0.049 & 2.280 & $0.038^{* *}$ & Supported \\
H4d & FRC $^{*}$ AILC -> SC & 0.108 & 0.885 & 0.371 & Unsupported \\
\hline
\end{tabular}

Notes: $p$ is significant at ${ }^{* *}(p<0.05)$.

Based on a PLS-based three-stage approach, assessing the higher-order construct requires building a new model in this stage using the latent variable score extracted at the first stage. From the latent variable score extracted at the first stage, a new model has been developed taking all the second-order constructs as an individual indicator. The PLS algorithm was run, and bootstrapping was done again (174 cases, 5000 samples). All the loadings and weights were significant, and the path coefficients were significant at the significance mentioned at the earlier level.

\subsection{Hypothesis Testing of Direct Relationship}

We tested the path relations of both the second-order and first-order constructs and found all the hypothesis relationships supported (see Table 4). According to the first hypothesis, H1a, the audit expectation gap (AEG) has been formed as a second-order construct with five distinct first-order constructs, such as the auditor's responsibility for fraud detection (ARF), the meaning and usefulness of the auditor's report (MUA), auditors providing non-audit services (NAS), the auditor's role for going concern reporting assessment (GCRA), and also the expectation for other assurance services (EOA). Moreover, the study has clinched that the audit expectation gap (AEG) is a matter of serious concern as, according to the result of H2, AEG negatively impacts the stakeholder's confidence (SC), and it pushes the regulators to enact regulatory initiatives to lessen the gap. Two vital initiatives might lessen the gap and retain the stakeholders' confidence in audits, such as the auditors' perceived independence (API) and how the auditors improve their level of communication (AILC). The auditor's perceived independence (API) has been constituted, through $\mathrm{H} 1 \mathrm{~b}$, as a second-order construct with some distinct first-order constructs, such as a restriction on providing non-audit services (RNAS), mandatory auditors rotation (MAR), and effective communication with the active audit committee (AAC). Moreover, the auditor's improved level of communication (AILC) concept has been formulated in the same way as a second-order construct, H1d, with the first-order construct, such as the expansion of the audit report (EAR) and ensuring audit education (EAED).

The results of $\mathrm{H} 1 \mathrm{c}, \mathrm{H} 1 \mathrm{e}, \mathrm{H} 3 \mathrm{a}$, and $\mathrm{H} 3 \mathrm{~b}$ clearly state that the auditors' perceived independence (API) and the auditor's improved level of communication (AILC) concept negatively impact the audit expectation gap, as well as positively impacting the stakeholders' confidence (SC). Hence, API and AILC contribute to lessening the audit expectation gap (AEG) and inducing the stakeholders' confidence (SC) concurrently. 


\subsection{Hypothesis Testing of Moderating Relationship}

The result of $\mathrm{H} 4 \mathrm{a}$ and $\mathrm{H} 4 \mathrm{~b}$ states that the moderating effect of the FRC on the relationship between the API and AEG is significant, whereas, between the AILC and AEG, it is not significant Consequently, the result of $\mathrm{H} 4 \mathrm{c}$ and $\mathrm{H} 4 \mathrm{~d}$ states the effect of the FRC on the relationship between the API and SC is significant, whereas, between the AILC and SC, it is not significant, at $p<0.1$ (see Table 5). This result confirms that the active role of the financial reporting council plays a vital part in maintaining the auditors' perceived independence that leads to ensuring a smaller audit expectation gaps and enhanced confidence in audits.

\section{Discussion}

This research is very pertinent as the regulators of the audit profession assess people's perception towards the audit, request annotations from the public, and take actions according to their desires to improve the value of the audit (Schelluch and Green 1996; PCAOB (2011a), 2011b; IAASB 2011, 2012, 2014, 2015a; Hanson 2016). The study delineates some important indications, such as in the basic questions (provided in Table 1), 47\% of the respondents including the auditors read audit reports where, based on a study, Porter (2009) mentioned that, in the U.K and New Zealand, $47 \%$ of the financial statement users do not read an entity's audit opinion. These show differences between the developed countries and the developing country's contexts, where fewer and fewer users go through the audit opinion. Moreover, $41 \%$ of the respondents decide based on the audit report and only $35 \%$ think that the audit practice of Bangladesh compares well with the international standards. These statistics will provide new insight into the regulators of the audit profession and will adhere to the improvement to achieve the stakeholders' confidence in the audit services.

Nonetheless, this study explores, in H1a, the audit expectation gap that exists from diverse facets such as the auditor's responsibility for fraud detection, the meaning and usefulness of the auditor's report, the auditor's role for providing the non-audit services, and also new insights of AEG have been identified, such as the auditor's responsibility for going concern reporting assessment, and also demands for other assurance services. The users think that the other parts of the annual report except for financial statements, such as management discussion and analysis and corporate social and environmental reports, are audited although they are not. Some of our findings are consistent with some previous research, such as AEG being mostly identified in the expanse of auditor errands for fraud prevention, and also the usefulness and dependability of the audit and audited financial statements in Egypt (Dixon et al. 2006); in Malaysia (Fadzly and Ahmad 2004); in Singapore (Best et al. 2001); in China (Lin and Chen 2004); in Iran (Pourheydari and Abousaiedi 2011); and in Germany (Ruhnke and Schmidt 2014). From the Bangladesh perspective, Chowdhury et al. (2005) ascertained AEG mostly in the area of accountability and audit independence in the public sector auditors of Bangladesh, and Siddiqui et al. (2009) portrayed that there is a significant audit expectation gap in Bangladesh in the area of the auditor's responsibility and, somewhere, the auditor's responsibility in fraud detection, while education plays an important role in reducing AEG in an emerging economy setup. Moreover, The study of Ruhnke and Schmidt (2014) in Germany illustrated that an independent financial statement audit is a tool for fraud prevention and considered as an early warning system for the company's failure as the findings showed most respondents believe that preventing fraud and making a going concern assessment is one of the auditor's main responsibilities.

Nevertheless, this study's objective was to determine which factors contribute to form the audit expectation gap, whether the audit expectation gap has any impact on the stakeholders' confidence, and how to mitigate the audit expectation gap to uphold the stakeholders' confidence in audits. The above paragraph discussed the audit expectation gap has been found from different aspects of the auditor's role, such as the auditor's responsibility for fraud detection, the meaning, and usefulness of the auditor's report, the auditor's role for providing non-audit services, the auditor's responsibility for going concern reporting assessment, and also demand for the other assurance services. These were included in our first research question. Our second research question was whether the audit 
expectation gap has any impact on the stakeholders' confidence. This study infers that, from the result of $\mathrm{H} 2$, the audit expectation gap negatively affects the stakeholders' confidence. The more the audit expectation will be, the lower the stakeholders' confidence in the audit. Our third research question was how to mitigate the audit expectation gap to uphold the stakeholders' confidence in the audit. The findings in $\mathrm{H} 3 \mathrm{a}$ and $\mathrm{H} 3 \mathrm{~b}$ delineate that having the auditor's maintain their perceived independence and improving the level of communication can lessen the audit expectation gap, as well as induce the stakeholders' confidence simultaneously. Moreover, the results of $\mathrm{H} 4 \mathrm{a}$ and $\mathrm{H} 4 \mathrm{c}$ dictate that the active role of independent audit oversight, such as the financial reporting council, can play a dynamic role in maintaining the auditor's perceived independence.

\section{Conclusions}

The study assesses the association of the audit expectation gap with the stakeholders' confidence empirically, taking the perception of the auditors, investors, credit and investment analysts, and regulatory agencies in Bangladesh during the period when the country had just entered into an era of independent audit regulation. The analytical result demonstrates that an audit expectation gap adversely affects the stakeholders' confidence. If the auditors maintain perceived independence and improve the level of communication, the audit expectation gap can be abridged, and the stakeholders will have superior confidence in the audit. The proper function of independent audit oversight, such as the financial reporting council, contributes to maintaining the auditors' perceived independence and ensuring greater confidence in the audit service. We resolutely consider that embracing and implementing this model will ensure a smaller audit expectation gap, and the stakeholders will feel more confident in the value of audit services. However, this study is accompanied with some limitations, such as this study constitutes the entire construct and items based on theoretical support from the pertinent literature, as we found no other empirical model in earlier studies relating the existence of an audit expectation gap with the stakeholders' confidence. As a symbol of independent audit oversight, we took the financial reporting council (FRC) as a moderating variable, and this is only a country-specific factor as Bangladesh has started the independent regulation of the audit profession by forming the FRC. Nevertheless, the study sheds light on evaluating the users' perception of the audit services and measuring the audit expectation gap and its consequences. Further examination is required to identify the factors that cause the audit expectation gap, as well as preventive measures to lessen those gaps and ensure greater confidence in the audit function and better inform the policymakers.

Data Accessibility Statement: The data that support the findings of this study are available from the corresponding author, upon reasonable request.

Author Contributions: T.A. wrote the first draft, collected data, performed the data analysis; T.A. \& F.X. designed the study, revised and finalized the paper. F.X. administered and supervised the project. All authors have read and agreed to the published version of the manuscript.

Funding: This research and the APC was funded by the National Social Science Foundation of China under project no.15BJY065.

Conflicts of Interest: Authors disclose no conflict of interest.

\section{Appendix A}

The measures of constructs and items are included in Table A1. The construct auditors' responsibility for fraud detection (ARF),Expectation for going concern reporting assessment (GCRA), Restriction on providing non-audit services (RNAS),Mandatory auditors' rotation (MAR) and Stakeholders' confidence (SC) are measured in 4 items scale. Meaning \& usefulness of audit report (MUAR) is measured in 5 items scale. Provision of Non-audit services (NAS), Expectation for other assurance services (EOA), Communication with the active audit committee (AAC), Expansion of audit report (EAR), Ensure audit education (EAED) and the role of Financial reporting council (FRC) are measured in 3 items scale. 
Table A1. List of Measures.

\begin{tabular}{|c|c|c|c|}
\hline Constructs & Items & Statement & Source \\
\hline \multirow{4}{*}{$\begin{array}{l}\text { Auditors' responsibility for } \\
\text { fraud detection (ARF) }\end{array}$} & ARF1 & $\begin{array}{l}\text { The auditor is primarily responsible for the prevention and detection of fraud } \\
\text { and error of the entity. }\end{array}$ & \multirow{4}{*}{$\begin{array}{c}\text { (IAASB 2009a; Pourheydari and Abousaiedi 2011; Dixon et al. 2006; } \\
\text { Ruhnke and Schmidt 2014; Siddiqui et al. 2009; Best et al. 2001; Lin } \\
\text { and Chen 2004; Stirbu 2010; McEnroe and Martens 2001; Porter 1993; } \\
\text { Porter and Gowthorpe 2004; Hogan et al. 2008; Salehi and Azary } \\
\text { 2009) }\end{array}$} \\
\hline & ARF2 & Auditor can detect all misstatements due to fraud and error. & \\
\hline & ARF3 & Auditor should be held responsible if the entity goes bankrupt due to fraud. & \\
\hline & ARF4 & $\begin{array}{l}\text { Auditor can conclude that there are no illegal operations conducted by the } \\
\text { audited company. }\end{array}$ & \\
\hline \multirow{5}{*}{$\begin{array}{l}\text { Meaning \& usefulness of audit } \\
\text { report (MUAR) }\end{array}$} & MUAR1 & $\begin{array}{l}\text { The standard unqualified report is a clean report and gives users significantly } \\
\text { high level of confidence in the company's management, investment } \\
\text { soundness, and accomplishment of strategic goal. }\end{array}$ & \multirow{5}{*}{$\begin{array}{l}\text { (Asare and Wright 2012; Mock et al. 2012; Coram et al. 2011; Gray } \\
\text { et al. 2011; Dixon et al. 2006) }\end{array}$} \\
\hline & MUAR2 & $\begin{array}{l}\text { A qualified opinion is used when the auditor's scope has been restricted by } \\
\text { clients or the auditor is not independent. }\end{array}$ & \\
\hline & MUAR3 & $\begin{array}{l}\text { Investors take investment decision; lenders take lending decision by observing } \\
\text { audit report. }\end{array}$ & \\
\hline & MUAR4 & The audit report is useful for assessing whether the company is well managed. & \\
\hline & MUAR5 & $\begin{array}{l}\text { Audited financial statements are useful for monitoring the performance of the } \\
\text { entity }\end{array}$ & \\
\hline \multirow{3}{*}{$\begin{array}{l}\text { Provision of Non-audit services } \\
\text { (NAS) }\end{array}$} & NAS1 & $\begin{array}{l}\text { auditors non-audit services do not increases economic dependency on client } \\
\text { and create threats to independence }\end{array}$ & \multirow{3}{*}{$\begin{array}{l}\text { (Kinney et al. 2004; Salehi and Rostami 2009; Wallman 1996; Wolf } \\
\text { et al. 1999; Zaman et al. 2011) }\end{array}$} \\
\hline & NAS2 & $\begin{array}{l}\text { If audit firm provides non audit services to the clients, it doesn't hampers the } \\
\text { auditor's independence. }\end{array}$ & \\
\hline & NAS3 & $\begin{array}{l}\text { If auditors apply safeguards to the threats arise as a result of providing non } \\
\text { audit services, Independence will not be hampered }\end{array}$ & \\
\hline \multirow{4}{*}{$\begin{array}{l}\text { Expectation for going concern } \\
\text { reporting assessment (GCRA) }\end{array}$} & GCR1 & $\begin{array}{l}\text { Auditor make an assessment of an entity's ability to continue as a going } \\
\text { concern }\end{array}$ & \multirow{4}{*}{$\begin{array}{l}\text { (IAASB 2009d, 2015a; Carson et al. 2012; Gray et al. 2011; Md Ali et al. } \\
\text { 2009) }\end{array}$} \\
\hline & GCR2 & $\begin{array}{l}\text { The auditors can conclude that the company will continue as a going concern } \\
\text { in the near future. }\end{array}$ & \\
\hline & GCR3 & $\begin{array}{l}\text { Auditor can forecast whether the entity has sufficient liquidity to operate } \\
\text { through the next year and can provide early warning of corporate failure. }\end{array}$ & \\
\hline & GCR4 & $\begin{array}{l}\text { Audit report should include the auditor's assessment of entity's ability to } \\
\text { continue as going concern }\end{array}$ & \\
\hline
\end{tabular}


Table A1. Cont.

\begin{tabular}{|c|c|c|c|}
\hline Constructs & Items & Statement & Source \\
\hline \multirow{3}{*}{$\begin{array}{l}\text { Expectation for other assurance } \\
\text { services (EOA) }\end{array}$} & EOA1 & $\begin{array}{l}\text { Investors find management commentary, directors report (MD\&A), } \\
\text { managememt performance analysis graphs and charts, CSR and } \\
\text { environmental report useful and they think that information are audited. }\end{array}$ & \multirow[t]{3}{*}{$\begin{array}{l}\text { (Bryan and Smith 1997; Mock et al. 2012; Mock et al. 2007; Simnett } \\
\text { et al. 2009; Brown-Liburd and Zamora 2014; Cohen et al. 2011) }\end{array}$} \\
\hline & EOA2 & CSR report become more credible when it is assured by auditor & \\
\hline & EOA3 & Entity require assurance on their sustainability information & \\
\hline \multirow{4}{*}{$\begin{array}{l}\text { Restriction on providing } \\
\text { non-audit services (RNAS) }\end{array}$} & RNAS1 & $\begin{array}{l}\text { Audit firm should not provide other services except audit like review, } \\
\text { consultancy and other attestation services to retain independence. }\end{array}$ & \multirow{4}{*}{$\begin{array}{c}\text { (Salehi and Rostami 2009; Beattie et al. 1999; Olagunju 2011; Wolf } \\
\text { et al. 1999; DeFond et al. 2002; Ashbaugh et al. 2003; Lim and Tan } \\
\text { 2008; Umar and Anandarajan 2004; Haddrill 2018) }\end{array}$} \\
\hline & RNAS2 & $\begin{array}{l}\text { Auditors can provide non audit services by taking appropriate safeguard so } \\
\text { that independence is not hampered. }\end{array}$ & \\
\hline & RNAS3 & $\begin{array}{l}\text { Prohibition on providing non audit services by the statutory auditors is } \\
\text { detrimental for management and it will increase the cost. }\end{array}$ & \\
\hline & RNAS4 & $\begin{array}{l}\text { Restriction on providing non audit services by the audit firm enhances audit } \\
\text { independence, therefore increase public trust and confidence. }\end{array}$ & \\
\hline \multirow{4}{*}{$\begin{array}{l}\text { Mandatory auditors' rotation } \\
\text { (MAR) }\end{array}$} & MAR1 & Mandatory Auditors Rotation enhances audit independence/quality & \multirow{4}{*}{ (Bazerman et al. 1997; Yip and Pang 2017; PCAOB 2011a) } \\
\hline & MAR2 & Earnings quality of the entity deteriorates with extended auditors' tenure & \\
\hline & MAR3 & $\begin{array}{c}\text { Mandatory Auditors Rotation is disruptive for management as the new } \\
\text { relationship is unpredictable }\end{array}$ & \\
\hline & MAR4 & $\begin{array}{l}\text { Mandatory Auditors Rotation increase audit startup cost and increase the risk } \\
\text { of audit failure }\end{array}$ & \\
\hline \multirow{3}{*}{$\begin{array}{l}\text { Communication with the active } \\
\text { audit committee (AAC) }\end{array}$} & AAC1 & $\begin{array}{l}\text { Auditors are required to maintain ongoing communication with the } \\
\text { specialized committee of the governing body such as Audit committee. }\end{array}$ & \multirow{3}{*}{$\begin{array}{l}\text { (IAASB 2009b, 2009c; Jensen and Meckling 1976; Salleh and Stewart } \\
\text { 2012; Krishnamoorthy et al. 2002) }\end{array}$} \\
\hline & AAC2 & $\begin{array}{l}\text { Presence of an effective audit committee can ensure auditors independence } \\
\text { and act as a guardian of public interest. }\end{array}$ & \\
\hline & AAC3 & $\begin{array}{l}\text { Audit committee should be independent of management and effectively } \\
\text { evaluate the financial reporting and internal control procedure. }\end{array}$ & \\
\hline \multirow{3}{*}{ Expansion of audit report (EAR) } & EAR1 & $\begin{array}{l}\text { Audit report should clarify the auditor's responsibility and management } \\
\text { responsibility in separate section and it increases the communicative value of } \\
\text { audit report. }\end{array}$ & \multirow{3}{*}{$\begin{array}{l}\text { (IAASB 2011, 2012, 2015a; Asare and Wright 2012; European } \\
\text { Commission 2010; Mock et al. 2012) }\end{array}$} \\
\hline & EAR2 & $\begin{array}{l}\text { If audit report includes the discussion about the key risk factors that } \\
\text { materially affects the entity and how auditors responded them, it will add } \\
\text { more values to the stakeholders. }\end{array}$ & \\
\hline & EAR3 & $\begin{array}{l}\text { Audit report should include the discussion about material uncertainty with } \\
\text { respect to entity's ability to continue as a going concern. }\end{array}$ & \\
\hline
\end{tabular}


Table A1. Cont.

\begin{tabular}{|c|c|c|c|}
\hline Constructs & Items & Statement & Source \\
\hline \multirow{3}{*}{ Ensure audit education (EAED) } & AEd1 & $\begin{array}{l}\text { Training program for shareholders specially discuss about role of audit in the } \\
\text { annual general meeting enhances better understanding about audit }\end{array}$ & \multirow{3}{*}{$\begin{array}{l}\text { (Siddiqui et al. 2009; Epstein and Geiger 1994; Monroe and Woodliff } \\
\text { 1994b) }\end{array}$} \\
\hline & AEd2 & $\begin{array}{l}\text { Public accounting firm should participate in local community activities of } \\
\text { college and universities in order to create a good impression for the profession }\end{array}$ & \\
\hline & AEd3 & $\begin{array}{l}\text { Incorporating more audit courses in the undergraduate level for the } \\
\text { accounting students in the university and incorporating case based class room } \\
\text { study about accounting scandal aware them about the role of auditors }\end{array}$ & \\
\hline \multirow{4}{*}{ Stakeholders' confidence (SC) } & SC1 & $\begin{array}{c}\text { Maintenance of auditor's perceived independence ensure stakeholders } \\
\text { confidence. }\end{array}$ & \multirow{4}{*}{$\begin{array}{l}\text { (FRC 2016; Okafor and Otalor 2013; Sikka et al. 1989; European } \\
\text { Commission 2010; IAASB 2015a; Baotham and Ussahawanitchakit } \\
\text { 2009; Xie 2016) }\end{array}$} \\
\hline & SC2 & $\begin{array}{c}\text { Greater competition in audit market ensures better independence and greater } \\
\text { confidence on audit }\end{array}$ & \\
\hline & SC3 & Meeting society's expectation ensure stakeholders confidence. & \\
\hline & SC4 & $\begin{array}{l}\text { communication about the purpose and scope of audit increases the users } \\
\text { understanding about audit and they feel confident about the audit services }\end{array}$ & \\
\hline \multirow{3}{*}{$\begin{array}{l}\text { Financial reporting council } \\
\text { (FRC) }\end{array}$} & FRC1 & $\begin{array}{l}\text { If an independent body e.g., Financial Reporting Council provides license to } \\
\text { auditors and approval of the audit firm, it enhances audit independence and } \\
\text { ensure public trust }\end{array}$ & \multirow{3}{*}{ (FRC 2016; Siddiqui 2018; Shil 2015; Ahmed 2017) } \\
\hline & FRC2 & $\begin{array}{l}\text { If an independent body e.g., Financial Reporting Council monitors the work } \\
\text { and conduct of all auditors and ensure the compliance with standard and } \\
\text { ethical requirements, un biasedness and objectivity will be ensured }\end{array}$ & \\
\hline & FRC3 & $\begin{array}{l}\text { Financial Reporting Council will invite political favorites, culture of biasness } \\
\text { and ultimately hampers auditors independence }\end{array}$ & \\
\hline
\end{tabular}


Table A2. Measurement of Audit Expectation gap. Note: The significant $p$ values in the Mann-Whitney-U test is regarded as the presence of audit expectation gap (AEG). ${ }^{* * *}(p<0.01),{ }^{* *}(p<0.05),{ }^{*}(p<0.1)$.

\begin{tabular}{|c|c|c|c|c|c|c|c|c|}
\hline \multirow{2}{*}{$\begin{array}{l}\text { Respondents Group } \\
\text { Statements of Differences }\end{array}$} & \multicolumn{2}{|c|}{ Auditors-Investors } & \multicolumn{2}{|c|}{ Auditors-Credit Analysts } & \multicolumn{2}{|c|}{$\begin{array}{l}\text { Auditors-Regulatory } \\
\text { Agencies }\end{array}$} & \multicolumn{2}{|c|}{ Auditors-Managers } \\
\hline & Z Values & $p$ Values & Z Values & $p$ Values & Z Values & $p$ Values & Z Values & $p$ Values \\
\hline \multicolumn{9}{|c|}{ (i) Auditor's responsibility for fraud detection: } \\
\hline $\begin{array}{l}\text { 1. The auditor is primarily responsible for the prevention and detection of fraud and error of the } \\
\text { entity. }\end{array}$ & -7 & $0.00^{* * *}$ & -8 & $0.00 * * *$ & -2.99 & $0.00 * * *$ & -0.9 & 0.37 \\
\hline 2. Auditor can detect all misstatements due to fraud and error. & -7.1 & $0.00^{* * *}$ & -7.8 & $0.00 * * *$ & -6.6 & $0.00 * * *$ & -8.7 & $0.00 * * *$ \\
\hline 3. Auditor should be held responsible if the entity goes bankrupt due to fraud. & -7.8 & $0.00^{* * *}$ & -8.6 & $0.00 * * *$ & -7.19 & $0.00^{* * *}$ & -3.6 & $0.00 * * *$ \\
\hline 4. Auditor can conclude that there are no illegal operations conducted by the audited company. & -7.7 & $0.00^{* * *}$ & -8.7 & $0.00^{* * *}$ & -7.23 & $0.00^{* * *}$ & -1.7 & $0.09 *$ \\
\hline \multicolumn{9}{|c|}{ (ii) Meaning \& usefulness of audit report } \\
\hline $\begin{array}{l}\text { 1. The unmodified audit report is a clean report and gives users significantly high level of confidence } \\
\text { in the company's management, investment soundness, and accomplishment of strategic goal. }\end{array}$ & -5 & $0.00^{* * *}$ & -8.4 & $0.00 * * *$ & -6.92 & $0.00^{* * *}$ & -0 & 0.98 \\
\hline $\begin{array}{l}\text { 2. A modified opinion is used when the auditor's scope has been restricted by clients or the auditor } \\
\text { is not independent. }\end{array}$ & -7.6 & $0.00^{* * *}$ & -8.5 & $0.00 * * *$ & -6.81 & $0.00^{* * *}$ & -8.8 & $0.00^{* * *}$ \\
\hline 3. Reasonable assurance means guarantee for the accuracy of the financial statements audited. & -7.5 & $0.00^{* * *}$ & -8.4 & $0.00 * * *$ & -6.91 & $0.00^{* * *}$ & -9.3 & $0.00 * * *$ \\
\hline 4. The audit report is useful for assessing whether the company is well managed. & -2.4 & $0.02 * *$ & -3 & $0.00 * * *$ & -0.95 & 0.34 & -0.7 & 0.46 \\
\hline 5. Audited financial statements are useful for monitoring the performance of the entity & -8 & $0.00 * * *$ & -8.6 & $0.00^{* * *}$ & -7.17 & $0.00^{* * *}$ & -9.5 & $0.00 * * *$ \\
\hline \multicolumn{9}{|c|}{ (iii) Provision of non-audit services: } \\
\hline $\begin{array}{l}\text { 24. Auditors non-audit services increases economic dependency on client and create threats to } \\
\text { independence. }\end{array}$ & -7.3 & $0.00^{* * *}$ & -8.7 & $0.00 * * *$ & -7.16 & $0.00^{* * *}$ & -9.7 & $0.00 * * *$ \\
\hline 25. If audit firm provides non audit services to the clients, it hampers the auditor's independence. & -4.2 & $0.00^{* * *}$ & -5.1 & $0.00^{* * *}$ & -4.47 & $0.00^{* * *}$ & -4.7 & $0.00^{* * *}$ \\
\hline $\begin{array}{l}\text { 26. If auditors apply safeguards to the threats arise as a result of providing non audit services, } \\
\text { Independence will not be hampered }\end{array}$ & -6.6 & $0 * * *$ & -4.7 & $0.00^{* * *}$ & -0.74 & $0.04^{* *}$ & -2 & 0.03 \\
\hline \multicolumn{9}{|c|}{ (iv) Auditor's responsibility for going concern reporting: } \\
\hline 24. Auditors makes an assessment of an entity's ability to continue as a going concern. & -6.6 & $0.00^{* * *}$ & -0.3 & 0.78 & -0.71 & 0.48 & -0.1 & 0.91 \\
\hline 25. The auditors can conclude that the company will continue as a going concern in the near future. & -7.6 & $0.00 * * *$ & -8.6 & $0.00^{* * *}$ & -7.18 & $0.00^{* * *}$ & -9.5 & $0.00 * * *$ \\
\hline 26. Auditor can forecast whether the entity has sufficient liquidity to operate through the next year. & -7.5 & $0.00^{* * *}$ & -8.4 & $0.00^{* * *}$ & -6.99 & $0.00^{* * *}$ & -0.6 & 0.55 \\
\hline 27. Auditor can provide early warning of corporate failure. & -5 & $0.00 * * *$ & -7.9 & $0.00 * * *$ & -0.03 & 0.98 & -0.4 & 0.66 \\
\hline \multicolumn{9}{|c|}{ (v) Expectation for other assurance services: } \\
\hline $\begin{array}{l}\text { 28. Information contained in the management commentary, directors' report, management } \\
\text { discussion \& analysis (MD\&A), management performance analysis graphs and charts, CSR and } \\
\text { environmental report are useful and that information are audited. }\end{array}$ & -2.5 & 0.01 ** & -4.1 & $0.00^{* * *}$ & -2.89 & $0.04^{* *}$ & -2.1 & $0.05^{* *}$ \\
\hline 29. CSR report become more credible when it is assured by auditor & -1.5 & $0.04 * *$ & -0.2 & $0.08 *$ & -3.39 & $0.08 *$ & -2.3 & $0.04 * *$ \\
\hline 30.Entity require assurance on their sustainability information & -2 & 0.03 ** & -6.1 & $0.00 * * *$ & -2.38 & $0.07 *$ & -2.4 & $0.07 *$ \\
\hline
\end{tabular}




\section{References}

Ahmed, Mustaq. 2017. Role and Responsibilities of Professional Accountants. Speech in Seminar on Financial Reporting Act, ICMAB News. The Cost and Management 45: 54.

American Institute of Certified Public Accountants (AICPA). 1978. Commission on Auditors, Responsibilities Report: Conclusions and Recommendations. New York: AICPA.

Akther, Taslima, and Fengju Xu. 2018. Stakeholders' Trust Towards the Role of Auditors: A Synopsis of Audit Expectation Gap. In 15th International Conference on Innovation \& Management. Wuhan: Wuhan University of Technology Press.

Andreev, Pavel, Tsipi Heart, Hanan Maoz, and Nava Pliskin. 2009. Validating Formative Partial Least Squares (PLS) Models: Methodological Review and Empirical Illustration. In Proceedings of ICIS 2009. Phoenix: AISeL.

Armstrong, Mary Beth, and Janice I. Vincent. 1988. Public accounting: A profession at a crossroads. Accounting Horizons 2: 94.

Asare, Stephen Kwaku, and Arnold M. Wright. 2012. Investors, Auditors, and Lenders Understanding of the Message Conveyed by the Standard Audit Report on the Financial Statements. Accounting Horizons 26: 193-217. [CrossRef]

Ashbaugh, Hollis, Ryan LaFond, and Brian W. Mayhew. 2003. Do Nonaudit Services Compromise Auditor Independence? Further Evidence. The Accounting Review 78: 611-39. [CrossRef]

Baker, C. Richard, Jean Bédard, and Christian Prat dit Hauret. 2014. The Regulation of Statutory Auditing: An Institutional Theory Approach. Managerial Auditing Journal 29: 371-94. [CrossRef]

Baotham, Sumintorn, and Phapruke Ussahawanitchakit. 2009. Audit Independence, Quality, and Credibility: Effects on Reputation and Sustainable Success of CPAs in Thailand. International Journal of Business Research 9: 1-25.

Barker, Patricia. 2002. Audit Committees: Solution to a Crisis of Trust? Accountancy Ireland 34: 6.

Bazerman, Max H., and Don Moore. 2011. Is it Time for Auditor Independence Yet? Accounting, Organizations and Society 36: 310-2. [CrossRef]

Bazerman, Max H., Kimberly P. Morgan, and George F. Loewenstein. 1997. The Impossibility of Auditor Independence. Sloan Management Review 38: 89-94.

Beattie, Vivien, Richard Brandt, and Stella Fearnley. 1999. Perceptions of Auditor Independence: U.K. Evidence. Journal of International Accounting, Auditing, and Taxation 8: 67-107. [CrossRef]

Becker, Jan-Michael, Kristina Klein, and Martin Wetzels. 2012. Hierarchical Latent Variable Models in PLS-SEM: Guidelines for Using Reflective-Formative Type Models. Long Range Planning 45: 359-94. [CrossRef]

Belal, Ataur, Crawford Spence, Chris Carter, and Jingqi Zhu. 2017. The Big 4 in Bangladesh: Caught between the Global and the Local. Accounting, Auditing \& Accountability Journal 30: 145-63.

Best, Peter, Sherrena Buckby, and Clarice Tan. 2001. Evidence of the Audit Expectation Gap in Singapore. Managerial Auditing Journal 16: 134-44. [CrossRef]

Broderick, Anne. 1999. Role Theory and the Management of Service Encounters. The Service Industries Journal 19: 117-31. [CrossRef]

Brown-Liburd, Helen, and Valentina L. Zamora. 2014. The role of corporate social responsibility (CSR) assurance in investors' judgments when managerial pay is explicitly tied to CSR performance. Auditing: A Journal of Practice \& Theory 34: 75-96.

Bryan, Barry J., and L. Murphy Smith. 1997. Faculty perspectives of auditing topics. Issues in Accounting Education 12: 1.

Burns, Alvin C., and Ronald F. Bush. 2003. Marketing Research: Online Research Applications. Upper Saddle River: Prentice Hall.

Carson, Elizabeth, Neil L. Fargher, Marshall A. Geiger, Clive S. Lennox, Kannan Raghunandan, and Marleen Willekens. 2012. Audit Reporting for Going-Concern Uncertainty: A Research Synthesis. AUDITING: A Journal of Practice \& Theory 32: 353-84.

Chowdhury, Riazur R., John Innes, and Reza Kouhy. 2005. The public sector audit expectations gap in Bangladesh. Managerial Auditing Journal 20: 893-908. [CrossRef]

Cohen, Jacob, and Patricia Cohen. 1983. Applied Multiple Regression/Correlation Analysis for Behavioral Sciences. Hillsdale: Lawrence Erlbaum Associates. 
Cohen, Jeffrey R., Lisa Milici Gaynor, Ganesh Krishnamoorthy, and Arnold M. Wright. 2011. The impact on auditor judgments of CEO influence on audit committee independence. Auditing: A Journal of Practice $\mathcal{E}$ Theory 30: 129-47.

Coram, Paul J., Theodore J. Mock, Jerry L. Turner, and Glen L. Gray. 2011. The Communicative Value of the Auditor's Report. Australian Accounting Review 21: 235-52. [CrossRef]

DeFond, Mark L., Kannan Raghunandan, and Subramanyam. 2002. Do Non-Audit Service Fees Impair Auditor Independence? Evidence from Going Concern Audit Opinions. Journal of Accounting Research 40: 1247-74. [CrossRef]

Diamantopoulos, Adamantios, and Judy A. Siguaw. 2000. Introducing LISREL. Thousand Oaks: Sage.

Diamantopoulos, Adamantios, and Judy A. Siguaw. 2006. Formative Versus Reflective Indicators in Organizational Measure Development: A Comparison and Empirical Illustration. British Journal of Management 17: $263-82$. [CrossRef]

Diamantopoulos, Adamantios, and Heidi M. Winklhofer. 2001. Index Construction with Formative Indicators: An Alternative to Scale Development. Journal of Marketing Research 38: 269-77. [CrossRef]

Dijkstra, Theo K. 2010. Latent Variables and Indices: Herman Wold's Basic Design and Partial Least Squares. In Handbook of Partial Least Squares: Concepts, Methods, and Applications (Springer Handbooks of Computational Statistics Series, Vol. II). Heidelberg and New York: Springer, pp. 23-46.

Dijkstra, Theo K., and Jörg Henseler. 2015. Consistent Partial Least Squares Path Modeling. MIS Quarterly 39: 297-316. [CrossRef]

Dijkstra, Theo Karin, and Karin Schermelleh-Engel. 2014. Consistent Partial Least Squares for Nonlinear Structural Equation Models. Psychometrika 79: 585-604. [CrossRef] [PubMed]

Dixon, R., A.D. Woodhead, and M. Sohliman. 2006. An investigation of the expectation gap in Egypt. Managerial Auditing Journal 21: 293-302. [CrossRef]

Edwards, Jeffrey R., and Richard P. Bagozzi. 2000. On the Nature and Direction of Relationships between Constructs and Measures. Psychological Methods 5: 155-74. [CrossRef]

Elliott, W. Brooke, Frank D. Hodge, Jane Jollineau Kennedy, and Maarten Pronk. 2007. Are M.B.A. Students a Good Proxy for Nonprofessional Investors? The Accounting Review 82: 139-68. [CrossRef]

Epstein, Marc J., and Marshall A. Geiger. 1994. Investor Views of Audit Assurance: Recent Evidence of the Expectation Gap. Journal of Accountancy 177: 60.

European Commission. 2010. Green Paper Audit Policy: Lessons from the Crisis. Available online: https: //eur-lex.europa.eu/legal-content/EN/TXT/?uri=CELEX:52010DC0561 (accessed on 22 December 2018).

Fadzly, Mohamed N., and Zauwiyah Ahmad. 2004. Audit Expectation Gap: The Case of Malaysia. Managerial Auditing Journal 19: 897-915. [CrossRef]

Financial Accounting Standard Board (FASB). 2008. Proposed Statement of Financial Accounting Standards, Going Concern. File Reference No. 1650-100. Norwalk: FASB.

Financial Accounting Standard Board (FASB). 2011. Disclosures about Risks and Uncertainties and the Liquidation Basis of Accounting. Norwalk: FASB.

Frank, Kimberly E., James K. Smith, and D. Jordan Lowe. 2001. The Expectation Gap: Perceptual Differences between Auditors, Jurors and Students. Managerial Auditing Journal 16: 145-50. [CrossRef]

Financial Reporting Council (FRC). 2016. Enhancing Confidence in the Value of Audit, A Research Report Commissioned by the Financial Reporting Council. Available online: https://www.frc.org.uk/getattachment/ 382e1ad9--5b7a--4297--849b1d415420fdc4/Impact--Assessment--Audit--Regulation--and--Directive-September--2015.pdf (accessed on 18 January 2018).

Gay, Grant, Peter Schelluch, and Ian Reid. 1997. Users Perceptions of the Auditing Responsibilities for the Prevention, Detection, and Reporting of Fraud, Other Illegal Acts and Error. Australian Accounting Review 7: 51-61. [CrossRef]

Gold, Anna, Ulfert Gronewold, and Christiane Pott. 2012. The ISA 700 Auditor's Report and the Audit Expectation Gap-Do Explanations Matter? International Journal of Auditing 16: 286-307. [CrossRef]

Gray, Glen L., Jerry L. Turner, Paul J. Coram, and Theodore J. Mock. 2011. Perceptions and Misperceptions Regarding the Unqualified Auditor's Report by Financial Statement Preparers, Users, and Auditors. Accounting Horizons 25: 659-84. [CrossRef] 
Haddrill, Stephen. 2011. Speech by Stephen Haddrill, Chief Executive of the U.K. Financial Reporting Council, to the European Commission Conference on Financial Reporting and Auditing on Thursday 10th February 2011. Available online: http://www.frc.org.uk/images/uploaded/documents/CEO\%20Audit\%20speech\% 20Brussels\%2010\%20Feb1.pdf (accessed on 10 August 2018).

Haddrill, Stephen. 2018. FRC's Annual Development Audit. Available online: https://www.frc.org.uk/ getattachment/f211c972-73ab-4bf2-b696-820eadc538bf/SH-Developments-in-Audit-FINAL-v2.pdf (accessed on 10 December 2018).

Hair, Joseph F., Rolph E. Anderson, Ronald L. Tatham, and William C. Black. 1995. Multivariate Data Analyses with Readings. New Jersey: Englewood Cliffs.

Hair, Joe F., Christian M. Ringle, and Marko Sarstedt. 2011. PLS-SEM: Indeed a Silver Bullet. Journal of Marketing Theory and Practice 19: 139-52. [CrossRef]

Hair, Joe F., Marko Sarstedt, Christian M. Ringle, and Jeannette A. Mena. 2012. An Assessment of the Use of Partial Least Squares Structural Equation Modeling in Marketing Research. Journal of the Academy of Marketing Science 40: 414-33. [CrossRef]

Hanson, J. D. 2016. PCAOB Update-Recent Activities and Next Steps. In 2016 SEC and Financial Reporting Institute Conference. Los Angeles: PCAOB.

Hendrickson, Harvey. 1998. Relevant Financial Reporting Questions not Asked by the Accounting Profession. Critical Perspectives on Accounting 9: 489-505. [CrossRef]

Hogan, Chris E., Zabihollah Rezaee, Richard A. Riley, and Uma K. Velury. 2008. Financial Statement Fraud: Insights from the Academic Literature. AUDITING: A Journal of Practice \& Theory 27: 231-52.

Hossen, Md Sahadat. 2016. Financial Reporting Act (FRA), 2015: A Revolutionary Era for Ensuring Effective Capital Market and Economic Development in Bangladesh. Global Journal of Management and Business Research 16: 13-20.

Howieson, Bryan. 2013. Quis Auditoret Ipsos Auditores? Can Auditors Be Trusted? Australian Accounting Review 23: 295-306. [CrossRef]

Humphrey, Christopher, Christopher Moizer, and Stuart Turley. 1992. The Audit Expectations Gap-Plus Ca Change, Plus C'est La Meme Chose? Critical Perspectives on Accounting 3: 137-61. [CrossRef]

Humphrey, Christopher, Peter Moizer, and Stuart Turley. 1993a. The Audit Expectations Gap in Britain: An Empirical Investigation. Accounting and Business Research 23: 395-411. [CrossRef]

Humphrey, Christopher, Stuart Turley, and Peter Moizer. 1993b. Protecting against Detection: The Case of Auditors and Fraud? Accounting, Auditing \& Accountability Journal 6: 39-62.

International Auditing \& Assurance Standard Board (IAASB). 2009a. ISA 240 Summary: The Auditor's Responsibilities Relating to Fraud in an Audit of Financial Statement. New York: IAASB.

International Auditing \& Assurance Standard Board (IAASB). 2009b. Communication with those Charged with Governance, ISA 260. New York: IAASB.

International Auditing \& Assurance Standard Board (IAASB). 2009c. Communicating Deficiencies in Internal Control to those Charged with Governance and Management, ISA 265. New York: IAASB.

International Auditing \& Assurance Standard Board (IAASB). 2009d. Going Concern, ISA 570. New York: IAASB.

IAASB. 2011. Enhancing the Value of Auditor Reporting: Exploring Options for Change. Available online: http: //www.ifac.org/sites/default/files/publications/exposure--drafts/CP_Auditor_Reporting--Final.pdf (accessed on 30 August 2018).

International Auditing \& Assurance Standard Board (IAASB). 2012. Invitation to Comment: Improving the Auditor's Report. New York: International Federation of Accountants.

IAASB. 2014. A Framework for Audit Quality, 1-6. Available online: https://www.ifac.org/auditing-assurance/ focus-audit-quality (accessed on 4 September 2018).

International Auditing \& Assurance Standard Board (IAASB). 2015a. The New Auditor's Report: Greater Transparency into the Financial Statement Audit. Available online: www.iaasb.org/auditor-reporting (accessed on 10 January 2019).

International Auditing \& Assurance Standard Board (IAASB). 2015b. Forming an Opinion and Reporting on Financial Statements, ISA700 Revised. New York: IAASB.

International Auditing \& Assurance Standard Board (IAASB). 2015c. Communicating Key Audit Matters in the Independent Auditor's Report, ISA 701. New York: IAASB. 
Institute of Chartered Accountants of England \& Wales (ICAEW). 2008. Reconciling Stakeholders Expectation of Audit. Audit Quality Forum. Available online: www.icaew.co.uk/auditquality (accessed on 5 January 2019).

International Federation of Accountants (IFAC). 2017. Legal and Regulatory Environment. IFAC, Bangladesh. Available online: https://www.ifac.org/about-ifac/membership/country/bangladesh (accessed on 12 September 2018).

Jamal, Karim, and Shyam Sunder. 2011. Is Mandated Independence Necessary for Audit Quality? Accounting, Organizations and Society 36: 284-92. [CrossRef]

Jarque, Carlos, and Anil Bera. 1980. Efficient tests for normality, homoscedasticity and serial independence of regression residuals. Econometric Letters 6: 255-25. [CrossRef]

Jensen, Michael C., and William H. Meckling. 1976. Theory of the Firm: Managerial Behavior, Agency Costs and Ownership Structure. Journal of Financial Economics 3: 305-60. [CrossRef]

Kinney, William. R., Jr., Zoe-Vonna Palmrose, and Susan Scholz. 2004. Auditor independence, non-audit services, and restatements: Was the US government right? Journal of Accounting Research 42: 561-88. [CrossRef]

Krishnamoorthy, Ganesh, Arnie Wright, and Jeffrey Cohen. 2002. Audit Committee Effectiveness and Financial Reporting Quality: Implications for Auditor Independence. Australian Accounting Review 12: 3-13. [CrossRef]

Md Ali, A., T. H. Lee, and Juergen Dieter Gloeck. 2009. The Audit Expectation Gap in Malaysia: An Investigation into its Causes and Remedies. Southern African Journal of Accountability and Auditing Research 9: 57-88.

Lim, Chee-Yeow-Y., and Hun-Tong Tan. 2008. Non-Audit Service Fees and Audit Quality: The Impact of Auditor Specialization. Journal of Accounting Research 46: 199-246. [CrossRef]

Lin, Z. Jun, and Feng Chen. 2004. An Empirical Study of Audit 'Expectation Gap' in the People's Republic of China. International Journal of Auditing 8: 93-115. [CrossRef]

McEnroe, John E., and Stanley C. Martens. 2001. Auditors' and Investors' Perceptions of the "Expectation Gap". Accounting Horizons 15: 345-58. [CrossRef]

Mo Koo, Chi, and Ho Seog Sim. 1999. On the role conflict of auditors in Korea. Accounting. Auditing $\mathcal{E}$ Accountability Journal 12: 206-19.

Mock, Theodore J., Christiane Strohm, and Kevin M. Swartz. 2007. An examination of worldwide assured sustainability reporting. Australian Accounting Review 17: 67-77. [CrossRef]

Mock, Theodore J., Jean Bédard, Paul J. Coram, Shawn M. Davis, Reza Espahbodi, and Rick C. Warne. 2012. The Audit Reporting Model: Current Research Synthesis and Implications. AUDITING: A Journal of Practice $\mathcal{E}$ Theory 32: 323-51.

Monroe, Gary S., and David R. Woodliff. 1993. The Effect of Education on the Audit Expectation Gap. Accounting $\mathcal{E}$ Finance 33: 61-78.

Monroe, Gary S., and David R. Woodliff. 1994a. Great Expectations: Public Perceptions of the Auditor's Role. Australian Accounting Review 4: 42-53. [CrossRef]

Monroe, Gary S., and David R. Woodliff. 1994b. An Empirical Investigation of the Audit Expectation Gap: Australian Evidence. Accounting \& Finance 34: 47-74.

Nachar, Nadim. 2008. The Mann-Whitney U: A test for assessing whether two independent samples come from the same distribution. Tutorials in Quantitative Methods for Psychology 4: 13-20. [CrossRef]

Nair, Raghavan, and Larry Rittenberg. 1987. Messages perceived from audit, review, and compilation reports: Extension to more diverse groups. Auditing: A Journal of Practice $\mathcal{E}$ Theory 7: 15-38.

Nelson, Mark W. 2006. Ameliorating Conflicts of Interest in Auditing: Effects of Recent Reforms on Auditors and their Clients. The Academy of Management Review 31: 30-42. [CrossRef]

Okafor, Chinwuba A., and John I. Otalor. 2013. Narrowing the expectation gap in auditing: the role of the auditing profession. Research Journal of Finance and Accounting 4: 43-52.

Olagunju, Adebayo. 2011. An Empirical Analysis of the Impact of Auditors Independence on the Credibility of the Financial Statement in Nigeria. Research Journal of Finance and Accounting 2: 82-99.

Public Company Accounting Oversight Board (PCAOB). 2011a. Concept Release on Auditor Independence and Audit Firm Rotation. Washington, DC: PCAOB.

Public Company Accounting Oversight Board (PCAOB). 2011b. Concept Release on Possible Revisions to PCAOB Standards Related to Reports on Audited Financial Statements and Related Amendments to PCAOB Standards. Washington: PCAOB.

Petter, Stacie, Detmar Straub, and Arun Rai. 2007. Specifying Formative Constructs in Information Systems Research. MIS Quarterly 31: 623-56. [CrossRef] 
Pickard, Jim, and Madison Marriage. 2018. Labour Consider Breaking up Big Four Accounting Firms. The Financial Times. September 21. Available online: https://www.ft.com/content/43fbd564-bc30-11e8-94b2-17176fbf93f5 (accessed on 12 December 2018).

Porter, Brenda. 1991. Narrowing the Audit Expectation-Performance Gap: A Contemporary Approach. Pacific Accounting Review 3: 1-36.

Porter, Brenda. 1993. An Empirical Study of the Audit Expectation-Performance Gap. Accounting and Business Research 24: 49-68. [CrossRef]

Porter, Brenda A. 2009. The Audit Trinity: The Key to Securing Corporate Accountability. Managerial Auditing Journal 24: 156-82. [CrossRef]

Porter, Brend, and Catherine Gowthorpe. 2004. Audit Expectation-Performance Gap in the United Kingdom in 1999 and Comparison with the Gap in New Zealand in 1989 and 1999. Edinburgh: The Institute of Chartered Accountants of Scotland.

Porter, Brenda, Jon Simon, and David J. Hatherly. 2008. Principles of External Auditing. Hoboken: John Wiley \& Sons, vol. 3.

Porter, Brenda, Ó hÓgartaigh C. Hogartaigh, and Rachel Baskerville. 2012. Audit Expectation-Performance Gap Revisited: Evidence from New Zealand and the United Kingdom. Part 1: The Gap in New Zealand and the United Kingdom in 2008. International Journal of Auditing 16: 101-29. [CrossRef]

Pourheydari, Omid, and Mina Abousaiedi. 2011. An Empirical Investigation of the Audit Expectations Gap in Iran. Journal of Islamic Accounting and Business Research 2: 63-76. [CrossRef]

Ringle, Christian M., Sven Wende, and Jan-Michael Becker. 2015. SmartPLS 3. Available online: http: //www.smartpls.com (accessed on 24 January 2019).

Ruhnke, Klaus, and Martin Schmidt. 2014. The Audit Expectation Gap: Existence, Causes, and the Impact of Changes. Accounting and Business Research 44: 572-601. [CrossRef]

Salehi, Mahdi, and Zhila Azary. 2009. Fraud Detection and Audit Expectation Gap: Empirical Evidence from Iranian Bankers. International Journal of Business and Management 3: 65-77. [CrossRef]

Salehi, Mahdi, and Vahab Rostami. 2009. Audit expectation gap: International evidence. International Journal of Academic Research 1.

Salleh, Zalailah, and Jenny Stewart. 2012. The Role of the Audit Committee in Resolving Auditor-Client Disagreements: A Malaysian Study. Accounting, Auditing \& Accountability Journal 25: 1340-72.

Schelluch, Peter, and Grant Gay. 2006. Assurance Provided by Auditors' Reports on Prospective Financial Information: Implications for the Expectation Gap. Accounting \& Finance 46: 653-76.

Schelluch, Peter, and Wendy Green. 1996. The Expectation Gap: The Next Step. Australian Accounting Review 6: 19-23. [CrossRef]

Shil, Nikhil Chandra. 2015. Stewardship, Transparency, Accountability, and Reporting [Star] Framework. A Journey Enlightening. The Cost and Management 43: 5-12.

Siddiqui, Javed. 2018. Making the Financial Reporting Council functional. The Financial Express. February 3. Available online: https://thefinancialexpress.com.bd/views/making-financial-reporting-council-functional1517669468 (accessed on 20 February 2019).

Siddiqui, Javed, Taslima Nasreen, and Aklema Choudhury-Lema. 2009. The Audit Expectations Gap and the Role of Audit Education: The Case of an Emerging Economy. Managerial Auditing Journal 24: 564-83. [CrossRef]

Sikka, Prem, Hugh Willmott, and Tony Lowe. 1989. Guardians of Knowledge and Public Interest: Evidence and Issues of Accountability in the UK Accountancy Profession. Accounting, Auditing \& Accountability Journal 2.

Sikka, Prem, Anthony Puxty, Hugh Willmott, and Christine Cooper. 1998. The Impossibility of Eliminating the Expectations Gap: Some Theory and Evidence. Critical Perspectives on Accounting 9: 299-330. [CrossRef]

Simnett, Roger, Ann Vanstraelen, and Wai Fong Chua. 2009. An assurance on sustainability reports: An international comparison. The Accounting Review 84: 937-67. [CrossRef]

Stephen, Kingsley. 2018. Auditing's Expectation Gap is Worse than ever Financial Times. The Financial Times. January 14. Available online: https://www.ft.com (accessed on 10 August 2018).

Stevenson, Mark. 2019. Can Auditors Close the Great Expectation Gap for Good? Pivot Magazine. February 2 CPA. Available online: https://www.cpacanada.ca/en/news/pivot-magazine/2019-01-02-expectation-gaproundtable (accessed on 10 February 2019).

Stirbu, Dan Aurelian A. 2010. Current Controversy on Audit Functions. In Annals of DAAAM \& Proceedings of the 21st International DAAAM Symposium. Vienna: DAAAM Interenational. 
Tavakol, Mohsen, and Reg Dennick. 2011. Making Sense of Cronbach's Alpha. International Journal of Medical Education 2: 53-55. [CrossRef]

Umar, Ahson, and Asokan Anandarajan. 2004. Dimensions of Pressures Faced by Auditors and its Impact on Auditors' Independence: A Comparative Study of the USA and Australia. Managerial Auditing Journal 19: 99-116. [CrossRef]

Van Riel, Allard CR, Jörg Henseler, Ildikó Kemény, and Zuzana Sasovova. 2017. Estimating Hierarchical Constructs Using Consistent Partial Least Squares: The Case of Second-Order Composites of Common Factors. Industrial Management \& Data Systems 117: 459-77.

Wallman, Steven MH. 1996. The future of accounting, part III: Reliability and auditor independence. Accounting Horizons 10: 76.

Wolf, Fran M., Gregory A. Claypool, and James A. Tackett. 1999. Audit Disaster Futures: Antidotes for the Expectation Gap? Managerial Auditing Journal 14: 468-78. [CrossRef]

Xie, Fujiao. 2016. Competition, Auditor Independence and Audit Quality. Ph.D. dissertation, University of Hawaii, Honolulu, HI, USA.

Yip, Peter Chi-Wan, and Elvy Pang. 2017. Investors' Perceptions of Auditor Independence: Evidence from Hong Kong. E-Journal of Social \& Behavioural Research in Business 8: 70-82.

Zaman, Mahbub, Mohammed Hudaib, and Roszaini Haniffa. 2011. Corporate governance quality, audit fees and nominees of Auditor Independence: Evidence from Hong \& Accounting. Journal of Business Finance $\mathcal{E}$ Accounting 38: 165-97.

(C) 2020 by the authors. Licensee MDPI, Basel, Switzerland. This article is an open access article distributed under the terms and conditions of the Creative Commons Attribution (CC BY) license (http://creativecommons.org/licenses/by/4.0/). 